\title{
Biosynthesis of the bis-prenylated alkaloids muscoride A and B
}

\author{
Mattila, Antti
}

2019-12-20

Mattila , A, Andsten , R-M , Jumppanen, M , Assante , M , Jokela , J , Wahlsten , M , Mikula

, K M , Sigindere , C, Kwak, D H, Gugger, M , Koskela , H, Sivonen , K, Liu , X ,

Yli-Kauhaluoma , J , Iwaï , H \& Fewer , D 2019 , ' Biosynthesis of the bis-prenylated

alkaloids muscoride A and B ' , ACS Chemical Biology , vol. 14 , no. 12 , pp. 2683-2690 . https://doi.org/10.1021/acs

http://hdl.handle.net/10138/322129

https://doi.org/10.1021/acschembio.9b00620

acceptedVersion

Downloaded from Helda, University of Helsinki institutional repository.

This is an electronic reprint of the original article.

This reprint may differ from the original in pagination and typographic detail.

Please cite the original version. 


\title{
Biosynthesis of the Bis-Prenylated Alkaloids Muscoride A and B
}

Antti Mattila ${ }^{1}$, Rose-Marie Andsten ${ }^{1}$, Mikael Jumppanen ${ }^{2}$, Michele Assante ${ }^{2}$, Jouni Jokela ${ }^{1}$, Matti Wahlsten ${ }^{1}$, Kornelia M. Mikula ${ }^{3}$, Cihad Sigindere ${ }^{4}$, Daniel H. Kwak ${ }^{4}$, Muriel Gugger ${ }^{5}$, Harri Koskela ${ }^{6}$, Kaarina Sivonen ${ }^{1}$, Xinyu Liu ${ }^{4}$, Jari Yli-Kauhaluoma ${ }^{2}$, Hideo Iwaï ${ }^{3}$, and David P. Fewer ${ }^{1, *}$

${ }^{1}$ Department of Microbiology, University of Helsinki, P.O. Box 56, Viikki Biocenter, Viikinkaari 9, FI-00014 Helsinki, Finland

${ }^{2}$ Drug Research Program, Division of Pharmaceutical Chemistry and Technology, Faculty of Pharmacy, University of Helsinki, P.O.Box 56, Viikinkaari 5 E, FI-00014 Helsinki, Finland

${ }^{3}$ Research Program in Structural Biology and Biophysics, Institute of Biotechnology, University of Helsinki, P.O. Box 65, FI-00014Helsinki, Finland

${ }^{4}$ Department of Chemistry, University of Pittsburgh, Pittsburgh, Pennsylvania 15260, United States

${ }^{5}$ Collection des Cyanobactéries, Département de Microbiologie, Institut Pasteur, 28 Rue du Docteur Roux, 75724 Cedex 15, 75015Paris, France

${ }^{6}$ VERIFIN, Department of Chemistry, University of Helsinki, P.O. Box 55, FI-00014 Helsinki, Finland

*corresponding author: david.fewer@helsinki.fi

\begin{abstract}
Prenylation is a common step in the biosynthesis of many natural products and plays an important role in increasing their structural diversity and enhancing biological activity. Muscoride $A$ is a linear peptide alkaloid that contain two contiguous oxazoles and unusual prenyl groups that protect the amino- and carboxy-termini. Here we identified the $12.7 \mathrm{~kb}$ muscoride (mus) biosynthetic gene clusters from Nostoc spp. PCC 7906 and UHCC 0398. The mus biosynthetic gene clusters encode enzymes for the heterocyclization, oxidation, and prenylation of the MusE precursor protein. The mus biosynthetic gene clusters encode two copies of the cyanobactin prenyltransferase, MusF1 and MusF2. The predicted tetrapeptide substrate of MusF1 and MusF2 was synthesized through a novel tandem cyclization route in only eight steps. Biochemical assays demonstrated that MusF1 acts on the carboxy-terminus while MusF2 acts on the amino-terminus of the tetrapeptide substrate. We show that the MusF2 enzyme catalyzes the reverse or forward prenylation of amino-termini from Nostoc spp. PCC 7906 and UHCC 0398, respectively. This finding expands the regiospecific chemical functionality of cyanobactin prenyltransferases and the chemical diversity of the cyanobactin family of natural products to include bis-prenylated polyoxazole linear peptides.
\end{abstract}

\section{Introduction}

Cyanobactins are a family of linear and macrocyclic natural products that are produced through posttranslational modification of short precursor proteins (1-3). These post-translational modifications include oxidation, heterocyclization, proteolytic cleavage, and prenylation (1,3-7). The prenylation of cyanobactins is performed by members of the ABBA prenyltransferase superfamily $(7,8)$. The structure of ABBA 
prenyltransferase consists of a central barrel of 10 antiparallel $\beta$-strands surrounded by $\alpha$-helices (9-11). The central barrel forms a catalytic chamber where substrate binding and catalysis occur (8-10). The cyanobactin prenyltransferases have a broad substrate tolerance and accept a range of linear and macrocyclic peptide substrates $(7,8)$. Prenylated natural products are widely distributed in bacteria and fungi $(12,13)$. Prenylation increases the lipophilicity of natural products and enhances their affinity for biological membranes $(14,15)$. Prenylated derivatives often show biological and pharmacological activities clearly distinct from their nonprenylated precursors (16), making these enzymes valuable biocatalysts in the structural modification of small molecules.

Muscoride A is a peptide alkaloid produced by the terrestrial freshwater cyanobacterium Nostoc muscorum IAM M-14 (17). This bisoxazole natural product contains two contiguous methyloxazole residues, and unusual carboxy- and amino-terminal prenyl groups, and displays modest antimicrobial activity (17). Muscoride A has a reverse prenyl on the $\alpha$-nitrogen of Val and a forward prenyl on the carboxyl group of the terminal methyloxazole (17). Muscoride A has served as a useful platform to test methods of oxazole construction, and a number of total synthesis methods have been accomplished (18-23). However, the biosynthetic origins of this peptide alkaloid remain unclear.

The structure of muscoride $A(17)$ suggests that it might be synthesized through post-translational modification of a precursor protein via the cyanobactin biosynthetic pathway. Here, we identify muscoride biosynthetic gene clusters from draft genome sequences, characterize a new muscoride variant, and demonstrate that the regioselective prenylation of this peptide alkaloid is catalyzed by two dedicated cyanobactin prenyltransferases that belong to the ABBA family of aromatic prenyltransferases.

\section{Identification of the Muscoride Biosynthetic Gene Cluster}

Muscoride A is reported from the cyanobacterium Nostoc muscorum IAM M-14.(17) We detected muscoride A (m/z 513.3) from Nostoc sp. PCC 7906, an identical pure strain held in the Pasteur Culture of Cyanobacteria, by HR-LC-MS (Figure S1). We extracted high-molecular-weight genomic DNA from Nostoc sp. PCC 7906 and obtained an $8.3 \mathrm{Mb}$ draft genome sequence. We identified a $12.7 \mathrm{~kb}$ cyanobactin biosynthetic gene cluster through tBLASTn searches using VirF1 and AgeF1 prenyltransferases from the viridisamide and aeruginosamide biosynthetic pathways (3) as query sequences against a standalone BLAST database. This putative muscoride (mus) gene cluster encoded 10 cyanobactin biosynthetic proteins organized in a bidirectional operon (Figure 1).

To demonstrate that the musA-G genes encode muscoride A production in vivo, we cloned the entire mus operon from Nostoc sp. PCC 7906 into a broad host range yeast/bacteria shuttle vector pMQ123i (24) placed downstream of a pTac promoter to generate the expression plasmid pDK-mus1. The pDK-mus1 and pMBI plasmids were used to cotransform Escherichia coli TOP10. The $\mathrm{pMBI}$ plasmid encodes four yeast mevalonate-dependent isoprenoid pathway biosynthetic genes that can convert mevalonate to isopentenyl pyrophosphate (IPP), a precursor to DMAPP (25). HR-LC-MS guided metabolite profiling of $E$. coli cells transformed with pDK-mus1 and pMBI plasmids revealed the presence of muscoride A, for which the LC retention time and HRMS profile matched authentic muscoride A from Nostoc sp. PCC 7906 (Figure 2). E. coli cells carrying pMQ123i alone did not produce muscoride A (Figure 2). These experiments established that the musA-G genes confer muscoride $\mathrm{A}$ biogenesis in vivo.

\section{Muscoride A Biosynthesis}

The mus biosynthetic gene cluster shares a set of core biosynthetic enzymes common in other cyanobactin pathways but nevertheless differs in a number of key areas (Figure 1). The organization of biosynthetic 
proteins encoded in the mus gene cluster suggests that muscoride A biosynthesis proceeds through the heterocyclization of Thr in the MusE precursor protein core by MusD to yield methyloxazolines followed by oxidation by MusOX to yield the methyloxazoles (Figure 1). The MusOX shares $73 \%$ identity with ThcOx from Cyanothece sp. PCC 7425 (26). The MusE precursor protein encodes a conserved leader sequence with an atypical QLDLSEEEL heterocyclization enzyme MusD recognition sequence (27). Heterocyclization is a widespread modification of Cys, Ser, and Thr in cyanobactin pathways (28).

However, thiazoles and oxazoles are not contiguous in the cyanobactins reported to date but are instead interspersed in the macrocycle (1). Natural products with multiple contiguous oxazoles, thiazoles, or both are rare in nature but include the macrocyclic telomerase inhibitor telomestatin from Streptomyces anulatus 3533-SV4 (29), the linear cytotoxic alkaloids tantazoles and mirabazoles from Scytonema mirabile BY-8-1 $(30,31)$, and the linear peptide antibiotics plantazolicins A and B from Bacillus amyloliquefaciens FZB42 (32). Some myxobacteria also produce natural products with multiple contiguous heterocycles including the antibiotics myxothiazole A (33) and althiomycin (34), as well as the antiviral thiangazol (35).

The mus biosynthetic gene cluster encoded an N-terminal protease, MusA, and a truncated C-terminal protease, MusG, which lacked the protease and macrocyclase domains entirely (Figure 1, Table S1). The mus biosynthetic gene cluster encoded MusE, an unusual 66 amino acid cyanobactin precursor protein with a conserved leader sequence, atypical cleavage recognition sequences, and a VPTT core sequence corresponding to the expected muscoride tetrapeptide backbone (Figure 1). A typical $\mathrm{N}$-terminal cleavage recognition sequence GVSPS is located directly before the cleavage site in the MusE precursor protein (Figure 1). However, the MusE precursor protein encodes an additional two amino acids (Gly and Val) after the VPTT core, which must be removed during maturation of muscoride. It is unclear how this might be achieved given the absence of either an obvious cleavage sequence or a functional C-terminal protease (Figure 1). It is possible that MusA catalyzes both proteolytic reactions, but this requires experimental validation (Figure $2 \mathrm{~A}$ ).

The mus gene cluster encoded two prenyltransferases, MusF1 and MusF2 (Figure 1). These two enzymes shared a sequence identity of $66 \%$. We hypothesized that these prenyltransferases would catalyze the forward O-prenylation and reverse N-prenylation of the excised tetrapeptide core.

\section{Genome-Driven Discovery of Muscoride B}

Bioinformatic analysis of public databases and unpublished Nostoc genomes identified 12 complete mus biosynthetic gene clusters (Figure S2). The 12 mus biosynthetic gene clusters shared a conserved gene order and encoded 10 cyanobactin biosynthetic enzymes that shared a sequence identity $\geq 88 \%$ at the nucleotide level compared to Nostoc sp. PCC 7906. The MusE precursor proteins shared near identical sequences (Figure 2). The precursor proteins differed mainly in the core sequence encoding predicted peptides with VPTT, VPTS, IPTS, IPSTS, or IPTSS sequences (Figure 2). Inspection of the Nostoc sp. UHCC 0398 MusE precursor protein core sequence suggested that the muscoride encoded in this biosynthetic gene cluster would contain three contiguous oxazoles (Figure 2). Mass spectrometry analysis of a methanol crude extract confirmed the production of the expected bis-prenylated pentapeptide muscoride variant from Nostoc sp. UHCC 0398 strain (m/z 580.3124, $\Delta-1.0$ ppm), which exactly matched the bioinformatics predictions (Figures S3 and S4). This muscoride variant from Nostoc sp. UHCC 0398 was named muscoride B. The musA-G genes from Nostoc sp. UHCC 0398 were cloned into the pMQ123i vector to create the pDKmus2 plasmid and used together with the pMBI plasmid to cotransform Escherichia coli TOP10 as previously described. Muscoride $B$ was detected from crude extracts of $E$. coli expressing the pDK-mus 2 and pMBI plasmids for which the $L C$ retention time and HRMS profile matched authentic muscoride $B$ from Nostoc sp. UHCC 0398 (Figure 2). 
Mass spectrometry analysis revealed the presence of muscoride B which after loss of two 68 Da units fits the linear structure of Ile-Pro-Ozl-mOzl-Ozl-carboxylic acid. This is the heterocyclized and oxidized form of the IPSTS peptide (Figure S3). Prominent losses of two 68 Da units in the ion source (MS) and trap (MS2) of an ion trap mass spectrometer (ITMS) from the protonated compound of muscoride B indicate the presence of two prenyl units connected to heteroatoms (Figure S3). Similar fragmentation of two 68.06 Da units from muscoride $B$ is seen in the high-resolution QTOF spectra, and the behavior is identical to that of muscoride $A$ (Figure S4). In addition to prenyl group fragmentation, the rest of the protonated muscoride $B$ molecule fragments in ITMS reside mainly between the subunits in a manner that is exactly identical to that of muscoride A (Figure S1 and Figure 3). With the sodium adduct of the molecular ion, the loss of $\mathrm{CO} 2$ was observed, but again, muscoride $B$ fragmentation was fully comparable to that of muscoride $A$. When muscoride $B$ was analyzed with QTOF, numerous small ion fragments were produced from which many can be explained only by fragments originating from the proton-deficient heterocyclic areas of the molecule (Figure S4).

Again, the product ion spectrum pattern was very similar compared to that of muscoride A (Figure S4). The ion masses of protonated and sodium adducts with 0-2 prenyl units match within $\pm 2.7 \mathrm{ppm}$ accuracy to the 0-2 prenylated Ile-Pro-Ozl-mOzl-Ozl-carboxylic acid pentapeptide structure. A methanol extract of $2.0 \mathrm{~g}$ of lyophilized cells of Nostoc sp. UHCC 0398 was fractionated in an SPE-cartridge to purify muscoride B. A sufficient amount $(20 \mu \mathrm{g})$ of purified muscoride B was subjected to a 1D and 2D NMR study to locate and determine the exact structure of prenyl moieties (Tables S2 and S3). This revealed the forward positions of prenyl groups for both the $\mathrm{C}$ - and $\mathrm{N}$-terminus (Figure 2 , Table S3). NMR analysis $(1 \mathrm{H}, 1 \mathrm{H}-1 \mathrm{H}$ COSY, $1 \mathrm{H}-1 \mathrm{H}$ TOCSY, $1 \mathrm{H}-1 \mathrm{H}$ ROESY, and $1 \mathrm{H}-13 \mathrm{C} \mathrm{HMBC}$ ) provided firm evidence for $\mathrm{N}$-prenylation of lle and prenyl ester of heterocyclized Ser (Figure S5 and Table S3). The muscoride $A$ and $B$ prenyl group $\delta \mathrm{H}$ and $\delta \mathrm{C}$ values closely matched with values from the forward prenyl attached to the $\mathrm{N}$-terminal and to the $\mathrm{C}$-terminal of aeruginosamide and virenamide (A, B)3, analogous reference compounds (Tables S2 and S3). We performed UV spectroscopy of pure muscoride $B$ to support the proposed structure of muscoride $B$ derived from MS and NMR data. Muscoride A shows a $252 \mathrm{~nm}$ UV absorption maximum in methanol (17) that originates from two conjugated oxazoles. Muscoride B shows an almost identical UV absorption maximum of $256 \mathrm{~nm}$, which suggests the presence of a highly similar aromatic chromophore system with the oxidized heterocyclized amino acids as in muscoride $A$ and in all other cyanobactins described with an oxazole structure (Figure S6, ref 1). All MS and NMR data obtained were in accordance with the proposed muscoride $\mathrm{B}$ structure. The $\mathrm{N}$ - and $\mathrm{C}$-terminal nitrogen and oxygen atoms in the muscoride $\mathrm{B}$ structure were the only heteroatoms that could bond prenyl groups. In principle, nitrogen atoms in heterocyclic rings and in Pro could bond with a prenyl group forming a quaternary cation. However, this has not been previously described. These results show that strains of the genus Nostoc can produce polyoxazole linear peptides with termini protected by prenyl groups. The cyanobactins described to date have dispersed thiazoles or oxazoles (1), and muscorides are the only reported cyanobactins with multiple contiguous oxazoles.

\section{Regiospecific Prenylation by MusF1 and MusF2}

Comparison of the chemical structures of muscoride $A$ and $B$ demonstrated regiospecific prenylation of the muscoride core sequences in the biosynthesis of muscorides by Nostoc spp. PCC 7906 and UHCC 0398 (Figures 1 and 2). The predicted tetrapeptide substrate of the MusF1 and MusF2 prenyltransferases, ValPro-mOzl-mOzl, was synthesized. Synthesis of this predicted biosynthetic intermediate 1 followed the previously published tandem cyclization route for multiple oxazole rings (36) (Scheme 1) with some modifications. Affordable and commercially available amino acids were used as building blocks for the synthesis of muscoride A precursor. First, Boc-protected I-Thr 2 was connected to I-Thr methyl ester hydrochloride 3 via (benzotriazol-1-yloxy)-tripyrrolidinophosphonium hexafluorophosphate (pyBOP)- 
mediated amide coupling. Boc protection was removed from the dipeptide 4 with trifluoroacetic acid in dichloromethane. Hydroxy groups of the formed dipeptide 5 were protected with triethylchlorosilane (TES$\mathrm{Cl}$ ) to give bis-triethylsilyl ether-protected dipeptide 6 that was subsequently coupled with Boc-Val-Pro-OH 7 in the presence of pyBOP and triethylamine. The formed tetrapeptide 8 was deprotected in situ and cyclodehydrated by diethylaminosulfur trifluoride (DAST) to give bisoxazoline 9 that, in turn, was oxidized in the presence of bromotrichloromethane and 1,8-diazabicyclo[5.4.0] undec-7-ene (DBU) to bisoxazole 10. Finally, bisoxazole 10 was hydrolyzed to give the carboxylic acid 11 followed by Boc deprotection with a 4 $\mathrm{M}$ solution of $\mathrm{HCl}$ in 1,4-dioxane to yield unprenylated muscoride $A$ precursor 1 (Scheme 1). $1 \mathrm{H}$ and $13 \mathrm{C}$ NMR spectra of synthesized compounds are presented in Figures S7-S14.

The genes encoding the MusF1 and MusF2 prenyltransferases from Nostoc spp. PCC 7906 and UHCC 0398 were cloned, overexpressed (Figure S15), and used in biochemical assays with the unprenylated muscoride A precursor 1. Nostoc sp. PCC 7906 produces bis-prenylated muscoride A 12 (Figure 3). Muscoride A core 1 subjected to MusF1 and MusF2 enzymes from Nostoc sp. PCC 7906 produces muscoride A 12 with matching retention times. However, muscoride A core 1 incubated with the MusF1 and MusF2 enzymes from Nostoc sp. UHCC 0398 produced bis-prenylated muscoride variant 14 with a retention time that did not match that of 12 , because of the forward prenyl in the amino-terminus instead of a reverse prenyl. MusF1 from both strains catalyzed the forward prenylation on the carboxy-terminus 17 with matching retention times. Nostoc sp. PCC 7906 also naturally produces amino-termini monoprenylated counterpart 15 , which had a matching retention time when 1 was subjected to the MusF2 enzyme from Nostoc sp. PCC 7906 to produce 15. The MusF2 from Nostoc sp. UHCC 0398 catalyzes forward prenylation on the aminoterminus 16 , which does not have a retention time identical to that of 15 , due to the reverse prenyl on the amino-terminus of 15 . Structures with forward prenyl(s) eluate later in LC, because forward prenyl is more hydrophobic compared to reverse prenyl. Nostoc sp. UHCC 0398 naturally produces muscoride B 13 and also amino-terminus monoprenylated counterpart 18 (Figure S16). Retention times of 18 and 13 have shifted later because of an additional heterocycle in the core compared to muscoride A 12 (Figure S16). This makes muscoride B more hydrophobic, and this led to later elution in LC (Figure S16). Peak areas supporting Figure 3 are presented in Table S4. This experiment showed that the MusF1 enzyme catalyzes the forward O-prenylation of the carboxy-terminus while the MusF2 enzyme catalyzes the N-prenylation of the amino-terminus (Figure 3). Both enzymes were tested together and individually in vitro. Our results show that monoprenylation was visible with a single enzyme and bisprenylation occurs in the presence of both enzymes. Moreover, the MusF1 enzymes from Nostoc spp. PCC 7906 and UHCC 0398 both catalyzed the forward prenylation of the carboxy-terminus. The two MusF2 enzymes differed notably as the MusF2 from Nostoc sp. PCC 7906 catalyzed reverse prenylation whereas MusF2 from Nostoc sp. UHCC 0398 catalyzed forward prenylation (Figure 3).

We also tested a range of synthetic substrates that contain thiazoles or oxazoles with free carboxy-and amino-termini to support our finding on regioselective prenylation with MusF1 and MusF2 from Nostoc sp. UHCC 0398. The MusF1 and MusF2 enzymes were tested independently and together providing evidence for the regioselective prenylation by these enzymes (Table S5). Prenylation is a ubiquitous posttranslational modification reaction, and prenyltransferases are important in enhancing structural diversity of numerous natural products families $(16,37,38)$.

\section{Phylogenetic Analysis of Cyanobactin Prenyltransferases}

The MusF1 and MusF2 prenyltransferases share $66 \%$ sequence identity. We constructed a sequence similarity network of 932 proteins sharing the ABBA aromatic prenyltransferase fold from the nonredundant database at NCBI (Figure 4). The cyanobactin prenyltransferases formed a distinct cluster separate from other ABBA aromatic prenyltransferases (Figure 4). We compared MusF1 and MusF2 to 40 characterized $A B B A$ aromatic prenyltransferases from different natural product pathways, including 
cyanobactins, indole alkaloids, and aminocoumarins (Figure 4). This analysis demonstrated that the MusF1 and MusF2 prenyltransferases are likely to be paralogous copies of genes resulting from a duplication event (Figure 4). The MusF1 and MusF2 enzymes appear to have arisen through duplication and subsequent specialization for prenylating the carboxy- and amino-termini of linear peptides. Prenylated natural product pathways frequently encode multiple prenyltransferases $(39,40)$, many of which are likely to have evolved through duplication events (Figure 4).

Natural product pathways encoding bis-prenylation include Penl and PenG prenyltransferases from the penigequinolone I biosynthetic pathway of Penicillium thymicola (39), a sequential prenylation cascade within echinulin biosynthesis by EchPT1 and EchPT2 from Aspergillus ruber (40), and bis-prenylation of paxilline by a single prenyltransferase JanD (41). Our results demonstrate that MusF1 and MusF2 catalyze the regiospecific prenylation of the peptide-termini to produce bis-prenylated muscorides. ABBA prenyltransferases are known to have a promiscuous substrate specificity (8). MusF2 from Nostoc sp. PCC 7906 reverse prenylates the amino-terminus, whereas MusF2 from Nostoc sp. UHCC 0398 forward prenylates the amino-terminus. The cyanobacterial prenyltransferase AmbP3 from Fischerella ambigua UTEX1903 was shown to have the ability to prenylate in forward or reverse orientations by this single enzyme using DMAPP (15). Here we show that MusF1 and MusF2 encode unusual prenyltransferases acting on peptide-termini. Prenylagaramides are known to be O-prenylated on Tyr (42), and trunkamides are Oprenylated on Thr and Ser (4). The N- and C-prenylation of Trp has recently been reported $(38,43)$. TruF prenyltransferase O-prenylates Thr, Tyr, and Ser on cyclic or linear peptide substrates (8). Linear aeruginosamides are prenylated on the $\mathrm{N}$-terminus and methylated on the $\mathrm{C}$-terminus by a bifunctional enzyme AgeMTPT (44). These results demonstrate that cyanobactin pathways are a rich source of regiospecific and stereospecific prenyltransferases that act on a variety of linear and macrocyclic peptides. Their promiscuity for different peptide substrates, solubility, and amenability to protein engineering make cyanobactin ABBA prenyltransferases attractive biocatalysts.

\section{Conclusions}

Cyanobactins are a rapidly growing family of natural products produced through post-translational modification of precursor proteins. We identified muscoride biosynthetic gene clusters by genome mining from Nostoc sp. PCC 7906 and Nostoc sp. UHCC 0398 and report the discovery of a new muscoride variant. We showed that MusF1 and MusF2 catalyze the specific prenylation of carboxyl- and amino-termini, respectively. This study expands the substrates of the cyanobactin ABBA prenyltransferases and hints at a rapid evolution in substrate preferences for an unusual family of aromatic prenyltransferases. Together this work expands the cyanobactin family to include linear polyoxazole bisprenylated peptides.

\section{Author Contributions}

The manuscript was written through contributions of all authors. All authors have given approval to the final version of the manuscript.

\section{Acknowledgements}

This work was supported by funding from the Academy of Finland (259505) and Novo Nordisk Foundation (180C0034838) to D.P.F., the Jane and Aatos Erkko foundation grant to K.S., and the NordForsk NCoE program "NordAqua" (Project Number 82845) to K.S. X.L. was supported by the University of Pittsburgh. M.A. was supported by the European University Consortium for Pharmaceutical Sciences (ULLA). A.M. was funded by the doctoral program of microbiology and biotechnology. The collection Pasteur Culture of 
Cyanobacteria is funded by the Institut Pasteur. M.G. acknowledges the LABGeM (CEA/Genoscope \& CNRS UMR8030) and the France Génomique and French Bioinformatics Institute national infrastructures (funded as part of Investissement d'Avenir program managed by Agence Nationale pour la Recherche, contracts ANR-10-INBS-09 and ANR-11-INBS-0013) for support within the MicroScope annotation platform. T. Kudling and B. Haas are acknowledged for cloning and protein productions of MusF1 and MusF2. S. Jääskeläinen and Z. Awol are acknowledged for their technical assistance.

\section{References}

1. Sivonen, K., Leikoski, N., Fewer, D. P., and Jokela, J. (2010) Cyanobactins-ribosomal cyclic peptides produced by cyanobacteria. Appl. Microbiol. Biotechnol. 86, 1213- 1225

2. Arnison, P. G., Bibb, M. J., Bierbaum, G., Bowers, A. A., Bugni, T. S., Bulaj, G., Camarero, J. A., Campopiano, D. J., Challis, G. L., Clardy, J., Cotter, P. D., Craik, D. J., Dawson, M., Dittmann, E., Donadio, S., Dorrestein, P. C., Entian, K., Fischbach, M. A., Garavelli, J. S., Göransson, U., Gruber, C. W., Haft, D. H., Hemscheidt, T. K., Hertweck, C., Hill, C., Horswill, A. R., Jaspars, M., Kelly, W. L., Klinman, J. P., Kuipers, O. P., Link, A. J., Liu, W., Marahiel, M. A., Mitchell, D. A., Moll, G. N., Moore, B. S., Müller, R., Nair, S. K., Nes, I. F., Norris, G. E., Olivera, B. M., Onaka, H., Patchett, M. L., Piel, J., Reaney, M. J. T., Rebuffat, S., Ross, R. P., Sahl, H., Schmidt, E. W., Selsted, M. E., Severinov, K., Shen, B., Sivonen, K., Smith, L., Stein, T., Süssmuth, R. D., Tagg, J. R., Tang, G., Truman, A. W., Vederas, J. C., Walsh, C. T., Walton, J. D., Wenzel, S. C., Willey, J. M., and Van der Donk, W. A. (2013) Ribosomally synthesized and post-translationally modified peptide natural products: Overview and recommendations for a universal nomenclature. Nat. Prod. Rep. 30, 108- 160

3. Leikoski, N., Liu, L., Jokela, J., Wahlsten, M., Gugger, M., Calteau, A., Permi, P., Kerfeld, C. A., Sivonen, K., and Fewer, D. P. (2013) Genome mining expands the chemical diversity of the cyanobactin family to include highly modified linear peptides. Chem. Biol. 20, 1033-1043

4. Donia, M. S., Ravel, J., and Schmidt, E. W. (2008) A global assembly line for cyanobactins. Nat. Chem. Biol. 4, 341- 343

5. Schmidt, E. W. and Donia, M. S. (2009) Cyanobactin ribosomally synthesized peptides-a case of deep metagenome mining. Methods Enzymol. 458, 575- 596

6. Czekster, C. M., Ge, Y., and Naismith, J. H. (2016) Mechanisms of cyanobactin biosynthesis. Curr. Opin. Chem. Biol. 35, 80-88

7. Gu, W., Dong, S., Sarkar, S., Nair, S. K., and Schmidt, E. W. (2018) The biochemistry and structural biology of cyanobactin pathways: Enabling combinatorial biosynthesis. Methods Enzymol. 604, 113- 163

8. Hao, Y., Pierce, E., Roe, D., Morita, M., McIntosh, J. A., Agarwal, V., Cheatham, T. E., III, Schmidt, E. W., and Nair, S. K. (2016) Molecular basis for the broad substrate selectivity of a peptide prenyltransferase. Proc. Natl. Acad. Sci. U. S. A. 113, 14037-14042

9. Kuzuyama, T., Noel, J. P., and Richard, S. B. (2005) Structural basis for the promiscuous biosynthetic prenylation of aromatic natural products. Nature 435, 983- 987

10. Metzger, U., Schall, C., Zocher, G., Unsöld, I., Stec, E., Li, S., Heide, L., and Stehle, T. (2009) The structure of dimethylallyl tryptophan synthase reveals a common architecture of aromatic prenyltransferases in fungi and bacteria. Proc. Natl. Acad. Sci. U. S. A. 106, 14309- 14314

11. Bonitz, T., Alva, V., Saleh, O., Lupas, A. N., and Heide, L. (2011) Evolutionary relationships of microbial aromatic prenyltransferases. PLoS One 6, e27336

12. Tello, M., Kuzuyama, T., Heide, L., Noel, J. P., and Richard, S. B. (2008) The ABBA family of aromatic prenyltransferases: Broadening natural product diversity. Cell. Mol. Life Sci. 65, 1459-1463 
13. Chen, R., Gao, B., Liu, X., Ruan, F., Zhang, Y., Lou, J., Feng, K., Wunsch, C., Li, S., Dai, J., and Sun, F. (2017) Molecular insights into the enzyme promiscuity of an aromatic prenyltransferase. Nat. Chem. Biol. 13, 226- 234

14. Botta, B., Vitali, A., Menendez, P., Misiti, D., and Monache, G. D. (2005) Prenylated flavonoids: Pharmacology and biotechnology. Curr. Med. Chem. 12, 713- 739

15. Wong, C. P., Awakawa, T., Nakashima, Y., Mori, T., Zhu, Q., Liu, X., and Abe, I. (2018) Two distinct substrate binding modes for the normal and reverse prenylation of hapalindoles by the prenyltransferase AmbP3. Angew. Chem., Int. Ed. 57, 560- 563

16. Winkelblech, J., Fan, A., and Li, S. (2015) Prenyltransferases as key enzymes in primary and secondary metabolism. Appl. Microbiol. Biotechnol. 99, 7379- 7397

17. Nagatsu, A., Kajitani, H., and Sakakibara, J. (1995) Muscoride A: A new oxazole peptide alkaloid from freshwater cyanobacterium Nostoc muscorum. Tetrahedron Lett. 36, 4097- 4100

18. Wipf, P. and Venkatraman, S. (1996) Total synthesis of (-)-Muscoride. J. Org. Chem. 61, 6517-6522

19. Muir, J. C., Pattenden, G., and Thomas, R. M. (1998) Total synthesis of (-)-muscoride A: A novel bisoxazole based alkaloid from the cyanobacterium Nostoc muscorum. Synthesis 1998, 613-618

20. Bagley, M. C., Buck, R. T., Hind, S. L., and Moody, C. J. (1998) Synthesis of functionalised oxazoles and bis-oxazoles. J. Chem. Soc., Perkin Trans. 1 591- 600

21. Coqueron, P. Y., Didier, C., and Ciufolini, M. A. (2003) Iterative oxazole assembly via $\alpha$ chloroglycinates: total synthesis of (-)-muscoride A. Angew. Chem., Int. Ed. 42, 1411- 1414

22. Amaike, K., Muto, K., Yamaguchi, J., and Itami, K. (2012) Decarbonylative C-H coupling of azoles and aryl esters: Unprecedented nickel catalysis and application to the synthesis of muscoride A. J. Am. Chem. Soc. 134, 13573-13576

23. Correa, A., Cornella, J., and Martin, R. (2013) Nickel-catalyzed decarbonylative C-H coupling reactions: A strategy for preparing Bis(heteroaryl) backbones. Angew. Chem., Int. Ed. 52, 18781880

24. Shanks, R. M. Q., Kadouri, D. E., MacEachran, D. P., and O'Toole, G. A. (2009) New yeast recombineering tools for bacteria. Plasmid 62, 88-97

25. Martin, V. J. J., Pitera, D. J., Withers, S. T., Newman, J. D., and Keasling, J. D. (2003) Engineering the mevalonate pathway in Escherichia coli for production of terpenoids. Nat. Biotechnol. 21, 796-802

26. Bent, A. F., Mann, G., Houssen, W. E., Mykhaylyk, V., Duman, R., Thomas, L., Jaspars, M., Wagner, A., and Naismith, J. H. (2016) Structure of the cyanobactin oxidase ThcOx from Cyanothece sp. PCC 7425 , the first structure to be solved at diamond light source beamline 123 by means of S-SAD. Acta Crystallogr. D Struct Biol. 72, 1174- 1180

27. Sardar, D., Pierce, E., McIntosh, J. A., and Schmidt, E. W. (2015) Recognition sequences and substrate evolution in cyanobactin biosynthesis. ACS Synth. Biol. 4, 167-176

28. Martins, J. and Vasconcelos, V. (2015) Cyanobactins from cyanobacteria: current genetic and chemical state of knowledge. Mar. Drugs 13, 6910-6946

29. Shin-ya, K., Wierzba, K., Matsuo, K., Ohtani, T., Yamada, Y., Furihata, K., Hayakawa, Y., and Seto, H. (2001) Telomestatin, a novel telomerase inhibitor from Streptomyces anulatus [17]. J. Am. Chem. Soc. $123,1262-1263$

30. Carmeli, S., Moore, R. E., Patterson, G. M. L., Corbett, T. H., and Valeriote, F. A. (1990) Tantazoles: Unusual cytotoxic alkaloids from the blue-green alga Scytonema mirabile. J. Am. Chem. Soc. 112, 8195- 8197

31. Carmeli, S., Moore, R. E., and Patterson, G. L. (1991) Mirabazoles, minor tantazole-related cytotoxins from the terrestrial blue-green alga Scytonema mirabile. Tetrahedron Lett. 32, 25932596 
32. Kalyon, B., Helaly, S. E., Scholz, R., Nachtigall, J., Vater, J., Borriss, R., and Süssmuth, R. D. (2011) Plantazolicin A and B: Structure elucidation of ribosomally synthesized thiazole/oxazole peptides from Bacillus amyloliquefaciens FZB42. Org. Lett. 13, 2996-2999

33. Trowitzsch, W., Reifenstahl, G., Wray, V., and Gerth, J. (1980) Myxothiazol, an antibiotic from Myxococcus fulvus (Myxobacterales). J. Antibiot. 33, 1480-1490

34. Kirst, H., Szymanski, E., Dorman, D., Occolowitz, J., Jones, N., Chaney, M., Hamill, R., and Hoehn, M. (1975) Structure of althiomycin. J. Antibiot. 28, 286- 291

35. Jurkiewicz, E., Jansen, R., Kunze, B., Trowitzsch-Kienast, W., Forche, E., Reichenbach, H., Höfle, G., and Hunsmann, G. (1992) Three new potent HIV-1 inhibitors from myxobacteria. Antiviral Chem. Chemother. 3, 189-193

36. Brandstätter, M., Roth, F., and Luedtke, N. W. (2015) Synthesis of 2-oxazolines by in situ desilylation and cyclodehydration of ß-hydroxyamides. J. Org. Chem. 80, 40-51

37. McIntosh, J. A., Donia, M. S., Nair, S. K., and Schmidt, E. W. (2011) Enzymatic basis of ribosomal peptide prenylation in cyanobacteria. J. Am. Chem. Soc. 133, 13698- 13705

38. Parajuli, A., Kwak, D. H., Dalponte, L., Leikoski, N., Galica, T., Umeobika, U., Trembleau, L., Bent, A., Sivonen, K., Wahlsten, M., Wang, H., Rizzi, E., De Bellis, G., Naismith, J., Jaspars, M., Liu, X., Houssen, W., and Fewer, D. P. (2016) A unique tryptophan C prenyltransferase from the kawaguchipeptin biosynthetic pathway. Angew. Chem., Int. Ed. 55, 3596- 3599

39. Zou, Y., Zhan, Z., Li, D., Tang, M., Cacho, R. A., Watanabe, K., and Tang, Y. (2015) Tandem prenyltransferases catalyze isoprenoid elongation and complexity generation in biosynthesis of quinolone alkaloids. J. Am. Chem. Soc. 137, 4980-4983

40. Wohlgemuth, V., Kindinger, F., Xie, X., Wang, B., and Li, S. (2017) Two prenyltransferases govern a consecutive prenylation cascade in the biosynthesis of echinulin and neoechinulin. Org. Lett. 19, 5928- 5931

41. Liu, C., Minami, A., Dairi, T., Gomi, K., Scott, B., and Oikawa, H. (2016) Biosynthesis of shearinine: Diversification of a tandem prenyl moiety of fungal indole diterpenes. Org. Lett. 18, 5026-5029

42. Donia, M. S. and Schmidt, E. W. (2011) Linking chemistry and genetics in the growing cyanobactin natural products family. Chem. Biol. 18, 508- 519

43. Dalponte, L., Parajuli, A., Younger, E., Mattila, A., Jokela, J., Wahlsten, M., Leikoski, N., Sivonen, K., Jarmusch, S. A., Houssen, W. E., and Fewer, D. P. (2018) N-Prenylation of tryptophan by an aromatic prenyltransferase from the cyanobactin biosynthetic pathway. Biochemistry 57, 6860-6867

44. Sardar, D., Hao, Y., Lin, Z., Morita, M., Nair, S. K., and Schmidt, E. W. (2017) Enzymatic N- and CProtection in cyanobactin RiPP natural products. J. Am. Chem. Soc. 139, 2884- 2887 


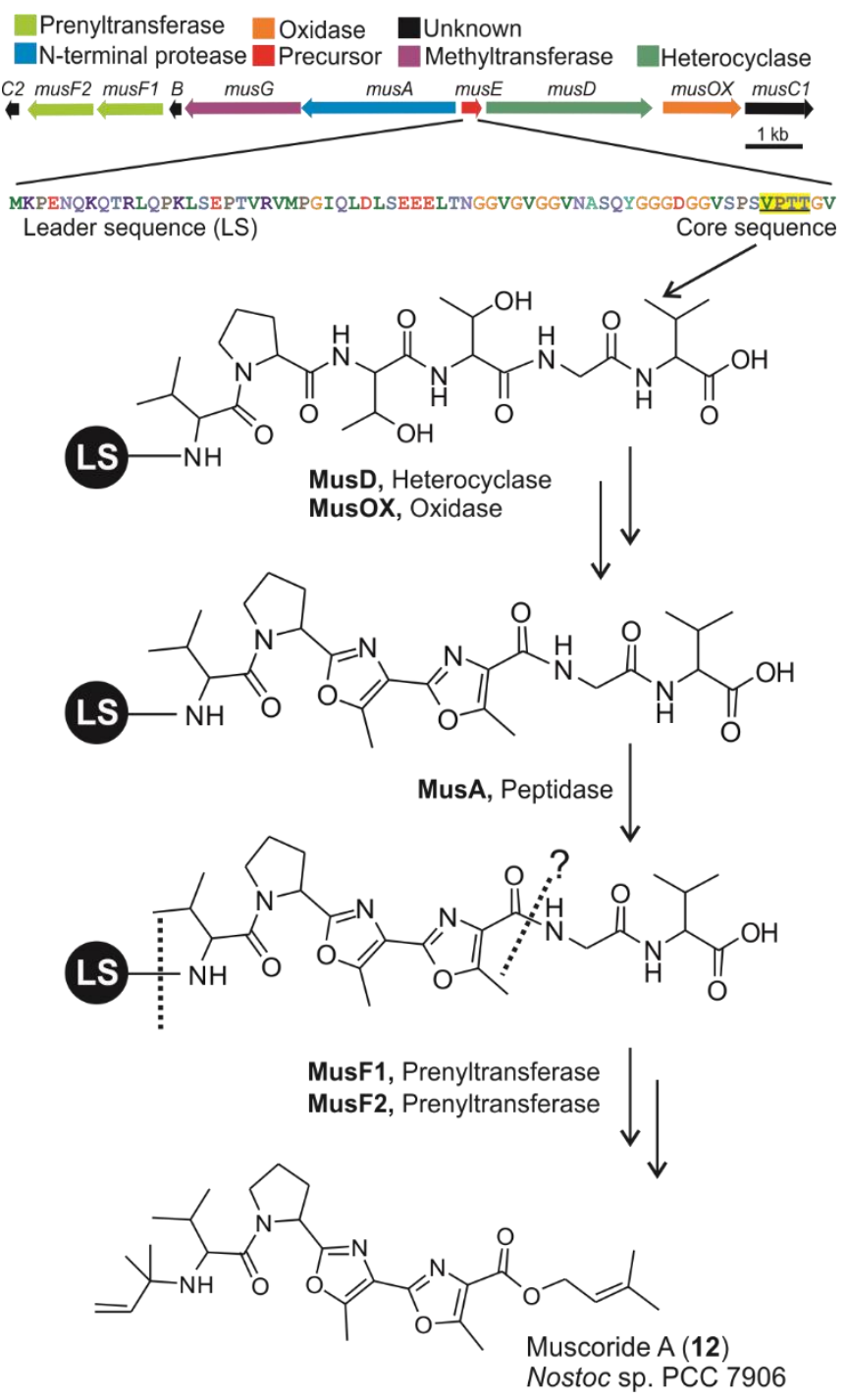

Figure 1. Muscoride (mus) biosynthetic gene cluster from Nostoc sp. PCC 7906 encoding the MusE precursor protein with leader sequence and a VPTT core. The mus biosynthetic gene cluster encodes two specific prenyltransferases, MusF1 and MusF2, which catalyze the formation of the muscoride A bisprenylated natural product (12). 


\section{A}

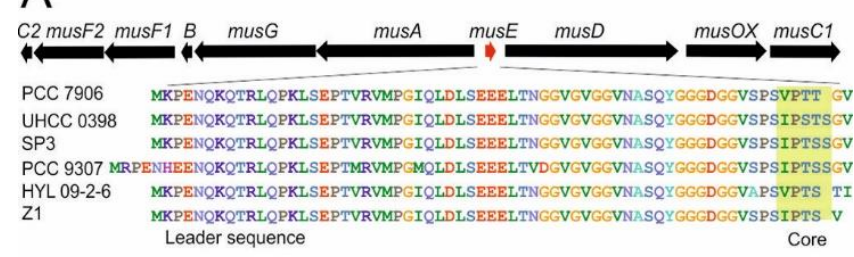

B

(13)

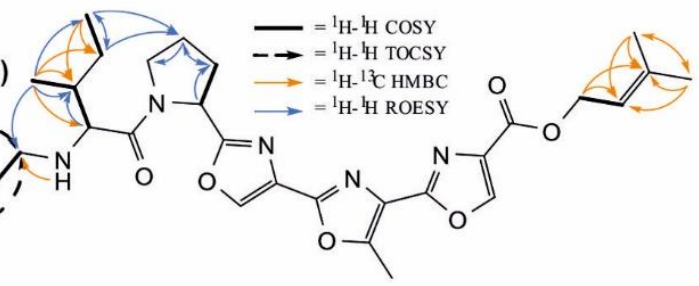

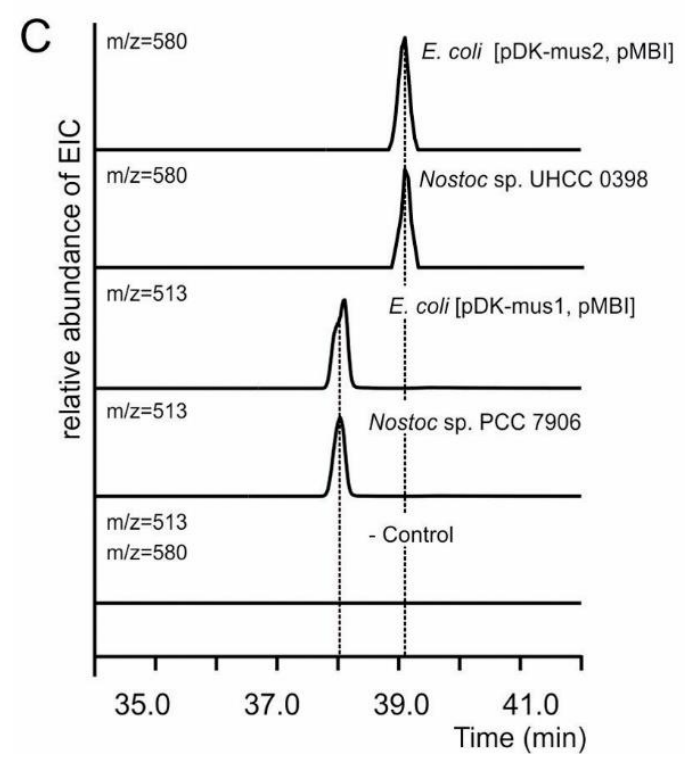

Figure 2. (A) Representative alignment of MusE precursor proteins showing the conserved leader and variable core sequences from various strains of Nostoc. (B) Muscoride B (13) from Nostoc sp. UHCC 0398. (C) Heterologous expression of mus biosynthetic gene clusters from Nostoc spp. PCC 7906 and UHCC 0398. 

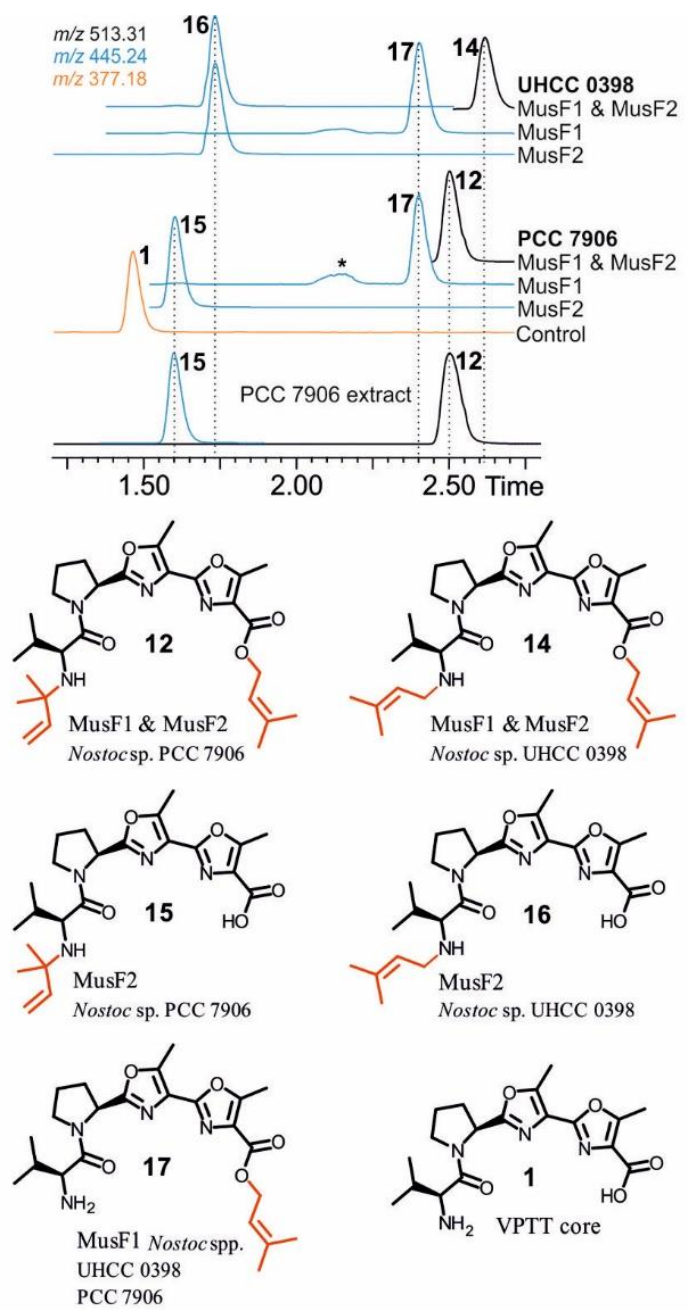

Figure 3. Biochemical assays demonstrating the regiospecific prenylation of the muscoride tetrapeptide precursor with MusF1 and MusF2 prenyltransferase Nostoc sp. PCC 7906 and Nostoc sp. UHCC 0398. * indicates MSE spectrum different from muscoride spectra.
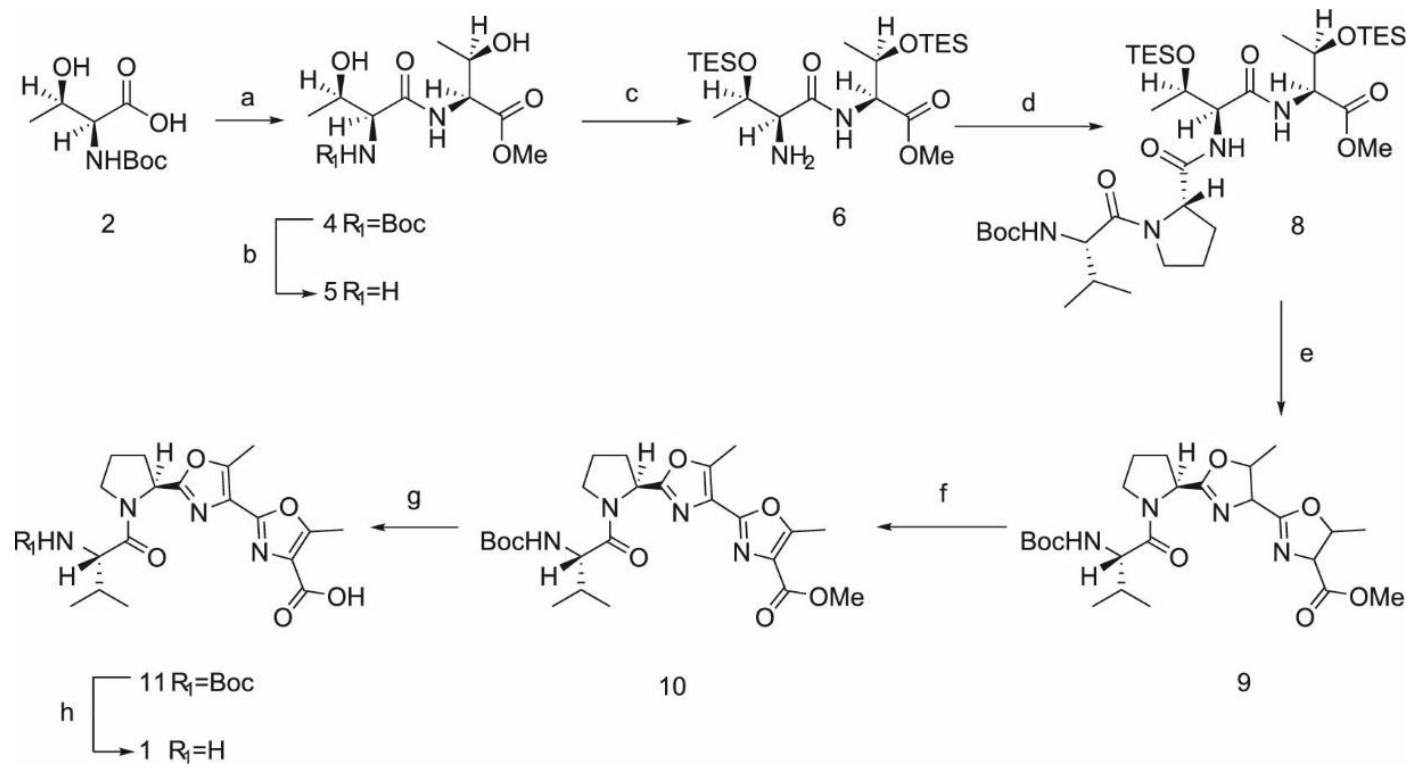
Scheme 1. (a) I-Threonine methyl ester (3), pyBOP/Et3N, CH2Cl2, rt, 16 h; (b) TFA/CH2Cl2 1:3, rt, 4 h; (c) TES-Cl, py, rt, 16 h, 49\%; (d) Boc-Val-Pro-OH (7), pyBOP/Et3N, CH2Cl2, rt, 16 h, 86\%; (e) DAST, CH2Cl2, -55 to $0{ }^{\circ} \mathrm{C}, 5$ h, $18 \%$; (f) $\mathrm{BrCCl} 3, \mathrm{DBU}, \mathrm{CH} 2 \mathrm{Cl} 2,16$ h, 25\%; (g) $\mathrm{NaOH}, \mathrm{MeOH} / \mathrm{THF}$, rt, 16 h, 32\%; (h) $4 \mathrm{M} \mathrm{HCl}$ in 1,4dioxane, $\mathrm{rt}, 3.5 \mathrm{~h}$, quant.

A

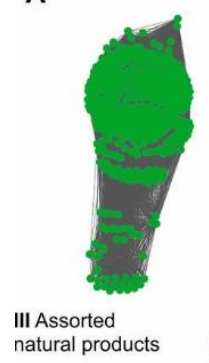

natural products
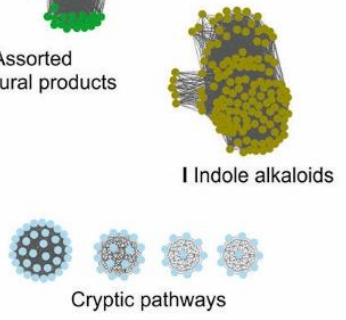

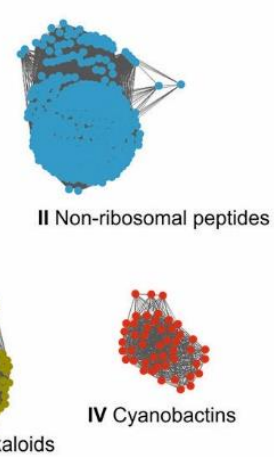

B

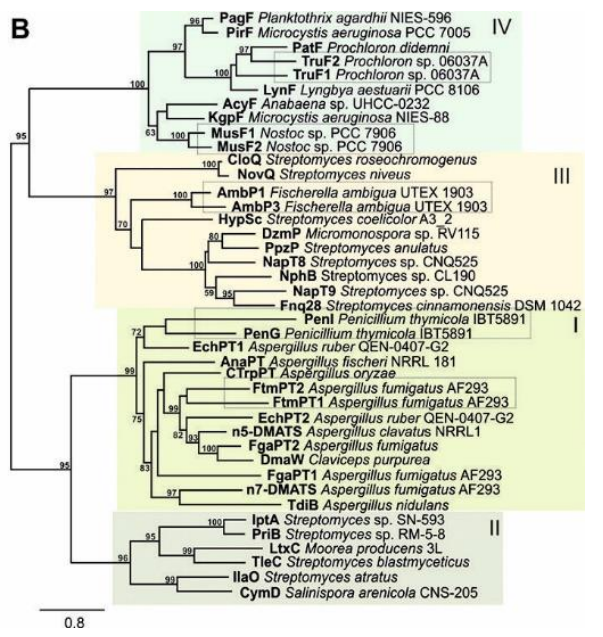

Figure 4. Sequence similarity network and phylogenetic analysis of relationships between members of the ABBA family of aromatic prenyltransferases. (A) Sequence similarity network based on 932 members of the ABBA family of aromatic prenyltransferases (alignment score of $\geq 20, \geq 21 \%$ sequence identity). Clusters with more than 10 representatives are shown. (B) Phylogeny of 42 ABBA aromatic prenyltransferases from a variety of natural product families showing the monophyly of cyanobactin prenyltransferases and the position of the MusF1 and MusF2 enzymes. 


\section{SUPPORTING INFORMATION}

\section{Regiospecific bisprenylation of the natural product muscoride by cyanobactin prenyltransferases}

Antti Mattila ${ }^{1}$, Rose-Marie Andsten ${ }^{1}$, Mikael Jumppanen², Michele Assante ${ }^{2}$, Jouni Jokela ${ }^{1}$, Matti Wahlsten ${ }^{1}$, Kornelia M. Mikula3 ${ }^{3}$ Cihad Sigindere ${ }^{4}$, Daniel H. Kwak4 ${ }^{4}$, Muriel Gugger Harri Koskela ${ }^{6}$, Kaarina Sivonen ${ }^{1}$, Xinyu Liu 4 , Jari Yli-Kauhaluoma ${ }^{2}$, Hideo Iwaï ${ }^{3}$, David P. Fewer $^{1, *}$

${ }^{1}$ Department of Microbiology, P.O. Box 56, Viikki Biocenter, Viikinkaari 9, FI-ooo14 University of Helsinki, Finland

${ }^{2}$ Drug Research Program, Division of Pharmaceutical Chemistry and Technology, Faculty of Pharmacy, Viikinkaari 5 E (P.O. Box 56), FI-ooo14 University of Helsinki, Helsinki, Finland

${ }^{3}$ Research Program in Structural Biology and Biophysics, P.O. Box 65, Institute of Biotechnology, FI-ooo14 University of Helsinki, Helsinki, Finland

4 Department of Chemistry, University of Pittsburgh, Pittsburgh, Pennsylvania 1526o, United States

${ }_{5}^{5}$ Collection des Cyanobactéries, Département de Microbiologie, Institut Pasteur, 28 Rue du Docteur Roux, 75724 Cedex 15, 75015 Paris, France

${ }^{6}$ VERIFIN, Department of Chemistry, University of Helsinki, P.O. Box 55, FIN-ooo14 Helsinki, Finland

*email for correspondence: david.fewer@helsinki.fi

Figure $\mathrm{S} 1$

Figure S2

Figure S3

Figure S4

Table S1

Figure S5

Table S2

Table S3

Figure S6

Figure S7

Figure S8

Figure S9

Figure S10

Figure S11

Figure S12

Figure S13

Figure S14

Figure S15

Table S4

Table S5

Table S6

Table S7
S-2

S-3

S -4

S-5

S-6

S-7-9

S-10

S-11

S-12

S-13

S-14

S-15

S-16

S-17

S-18

S-19

S-20

S-21

S-22

$\mathrm{S}-23$

$\mathrm{S}-24$

S-25 


\section{PCC 7906}

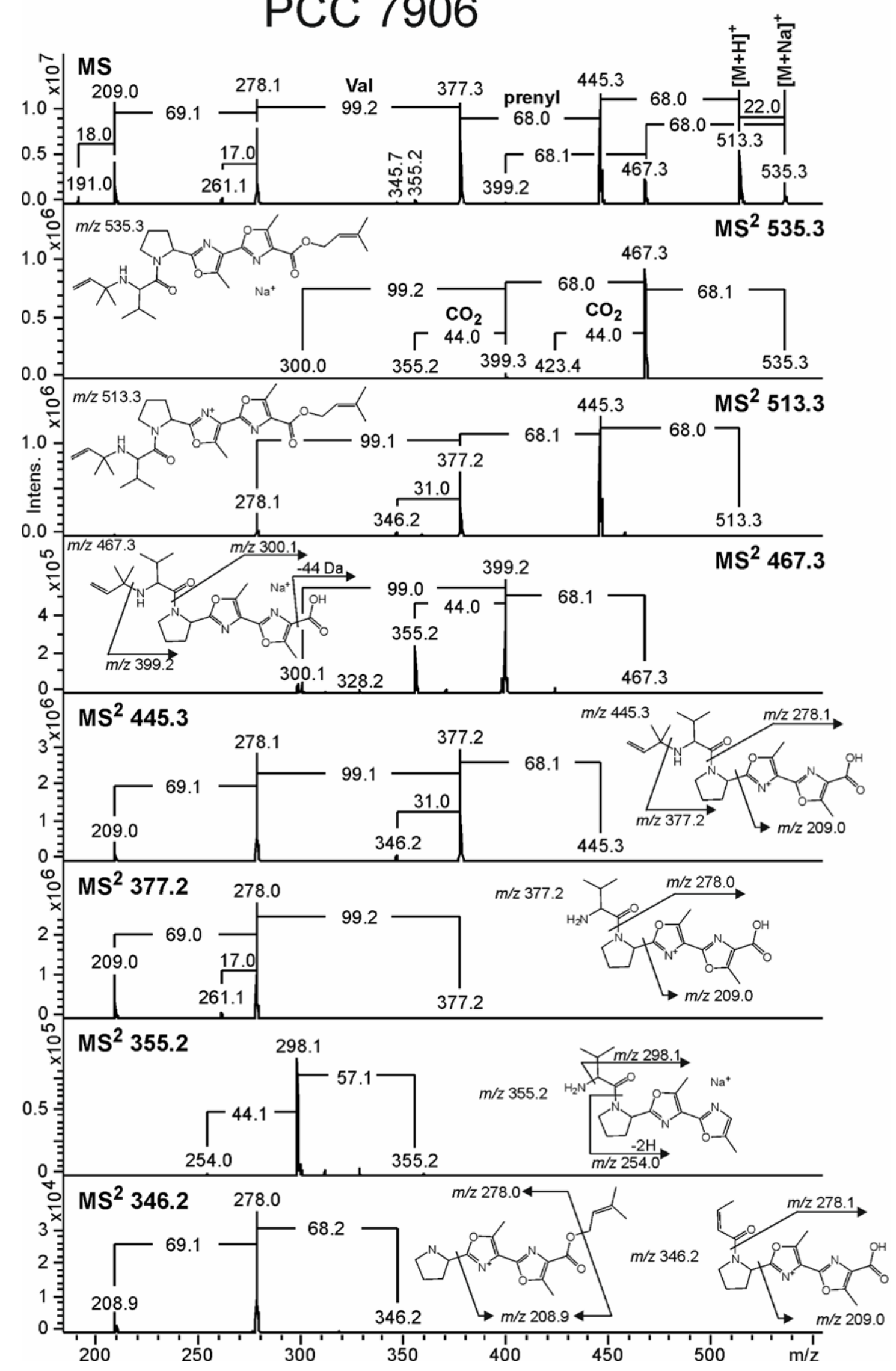

Figure S1. Ion trap mass spectrum (MS) and product ion mass spectra (MS2) of protonated $[\mathrm{M}+\mathrm{H}]^{+}$and sodiated $[\mathrm{M}+\mathrm{Na}]^{+}$muscoride A from Nostoc sp. PCC 7906. 


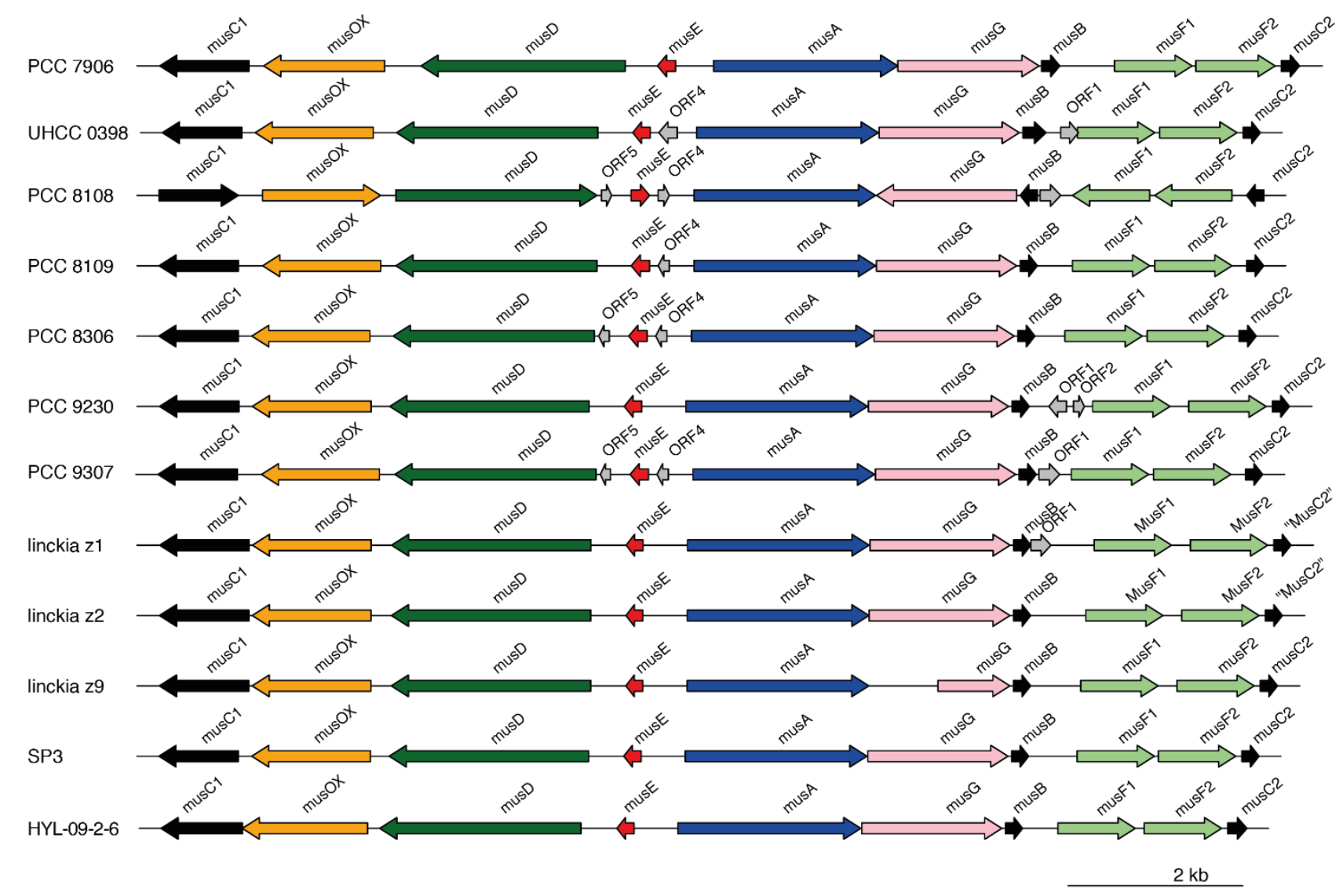

Figure S2. Conservation of gene order in 12 complete mus biosynthetic gene clusters from a variety of strains of the genus Nostoc. 


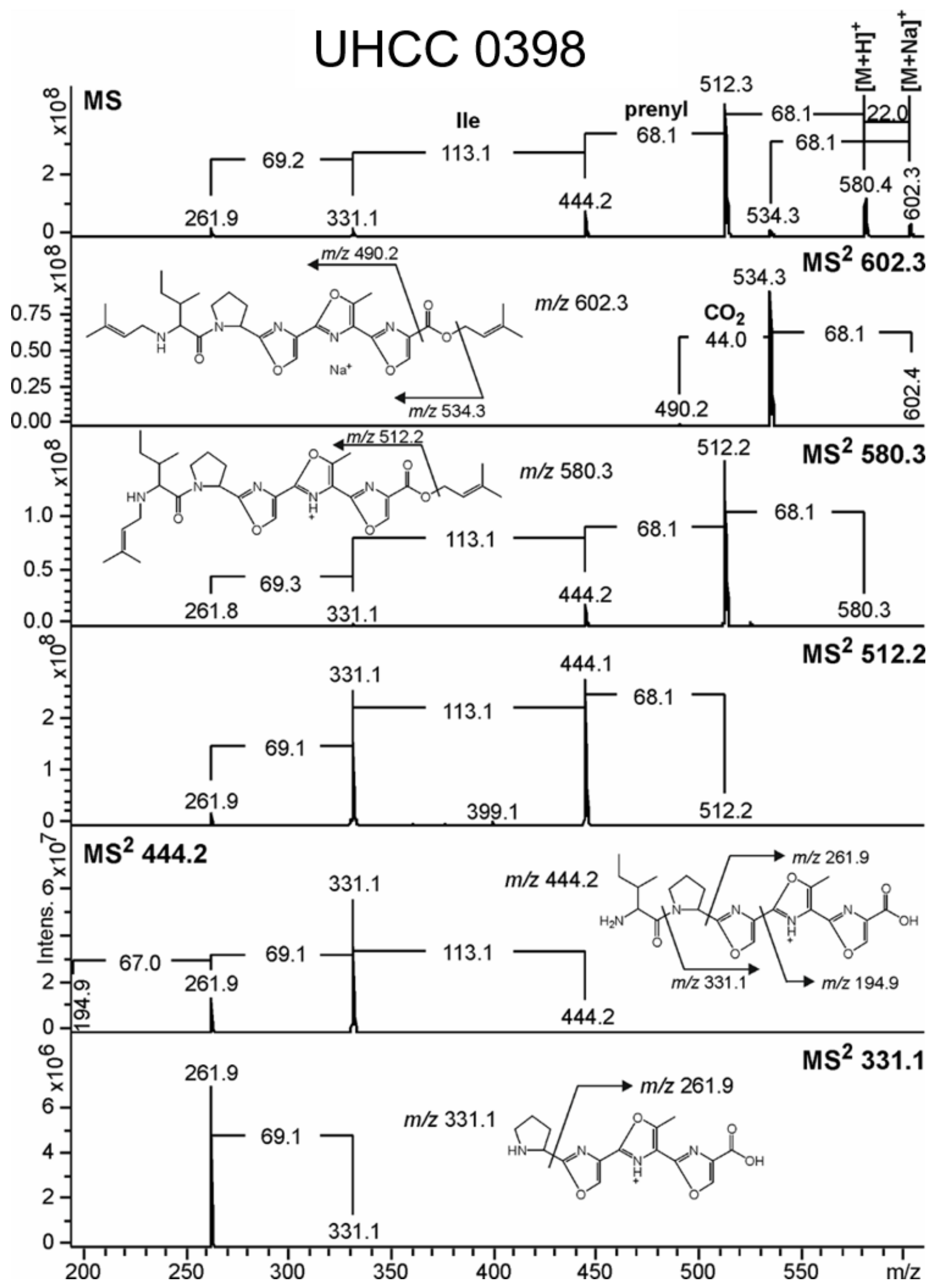

Figure S3. Ion trap mass spectrum (MS) and product ion mass spectra (MS2) of protonated $[\mathrm{M}+\mathrm{H}]^{+}$and sodiated $[\mathrm{M}+\mathrm{Na}]^{+}$muscoride B from Nostoc sp. UHCC-0398. 

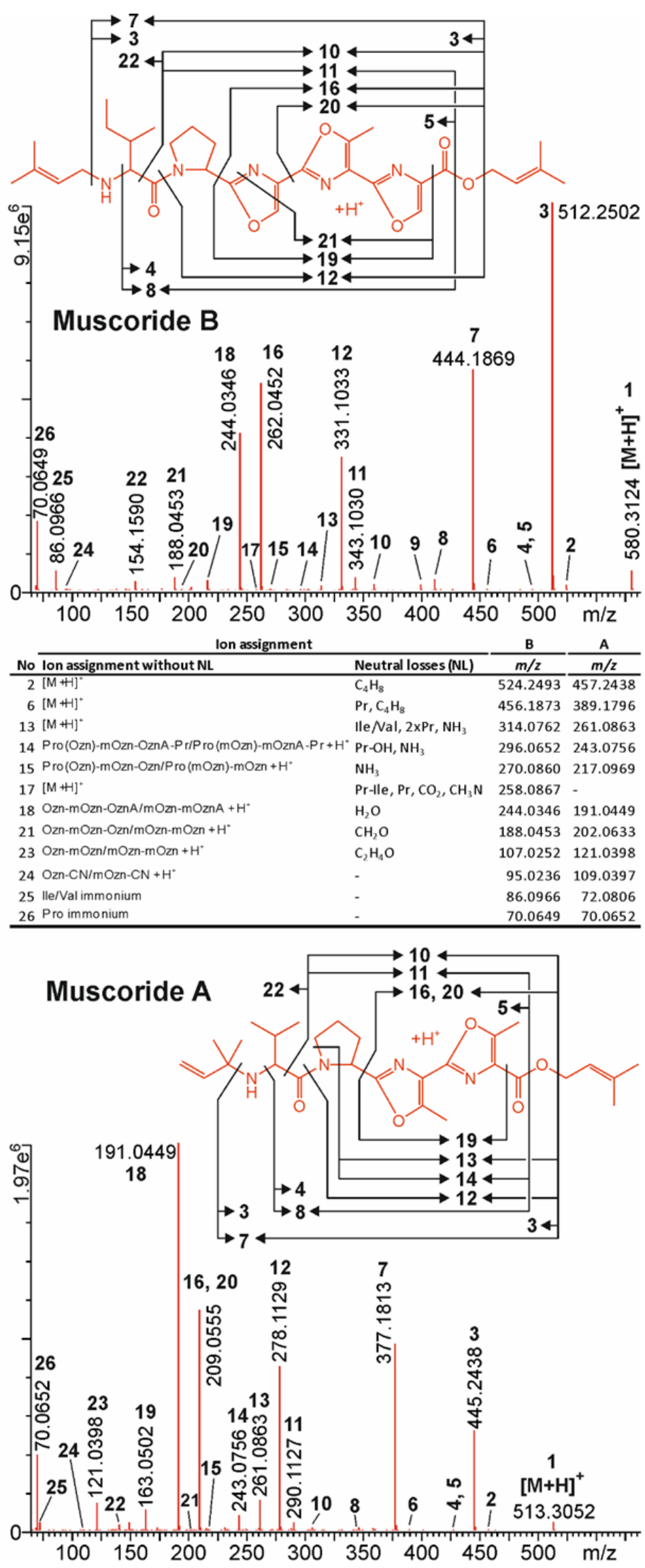

Figure S4. Annotated high resolution QTOF product ion mass spectra (MS2) of protonated $[\mathrm{M}+\mathrm{H}]^{+}$muscoride $\mathrm{B}$ and $\mathrm{A}$ with their structures and fragmentation schemes. 
Table S1. Annotation of the mus gene cluster from Nostoc sp. PCC 7906.

\begin{tabular}{|c|c|c|c|c|c|c|}
\hline \multicolumn{3}{|c|}{ Nostoc sp. PCC 7906} & \multicolumn{4}{|l|}{ Blastp results } \\
\hline Protein & Length & $\begin{array}{l}\text { Predicted } \\
\text { function }\end{array}$ & Description & $\begin{array}{l}\text { Identity } \\
\text { (aa \%) }\end{array}$ & Organism & Accession \\
\hline MusA & 706 & N-terminal protease & $\begin{array}{l}\text { PatA/PatG family cyanobactin } \\
\text { maturation protease }\end{array}$ & 93 & Nostoc linckia & WP_099068419 \\
\hline MusH & 544 & Methyltransferase & $\begin{array}{l}\text { PatA/PatG family cyanobactin } \\
\text { maturation protease }\end{array}$ & 95 & Nostoc linckia & WP_099068420 \\
\hline MusB & 66 & Unknown & $\begin{array}{l}\text { Cyanobactin biosynthesis system } \\
\text { PatB/AcyB/McaB family protein }\end{array}$ & 100 & Nostoc linckia & WP_099068421 \\
\hline MusF1 & 300 & $\begin{array}{l}\text { Putative C-terminal } \\
\text { prenyltransferase }\end{array}$ & $\begin{array}{l}\text { LynF/TruF/PatF family peptide } \\
O \text {-prenyltransferase }\end{array}$ & 95 & Nostoc linckia & WP_099072935 \\
\hline MusF2 & 303 & $\begin{array}{l}\text { Putative N-terminal } \\
\text { prenyltransferase }\end{array}$ & $\begin{array}{l}\text { LynF/TruF/PatF family peptide } \\
O \text {-prenyltransferase }\end{array}$ & 66 & Nostoc linckia & WP_099072934 \\
\hline MusE & 66 & Precursor peptide & Hypothetical protein & 97 & Nostoc linckia & WP_099068418 \\
\hline MusD & 781 & Heterocyclase & Adenylate cyclase & 96 & Nostoc linckia & WP_099068417 \\
\hline MusG & 461 & Oxidase & $\begin{array}{l}\text { SagB/ThcOx family } \\
\text { dehydrogenase }\end{array}$ & 95 & Nostoc linckia & WP_099068416 \\
\hline MusC1 & 301 & Unknown & $\begin{array}{l}\text { Cyanobactin biosynthesis } \\
\text { PatC/TenC/TruC family protein }\end{array}$ & 84 & Nostoc linckia & WP_099076588 \\
\hline MusC2 & 70 & Unknown & $\begin{array}{l}\text { Cyanobactin biosynthesis } \\
\text { PatC/TenC/TruC family protein }\end{array}$ & 90 & Nostoc linckia & WP_099072933 \\
\hline
\end{tabular}



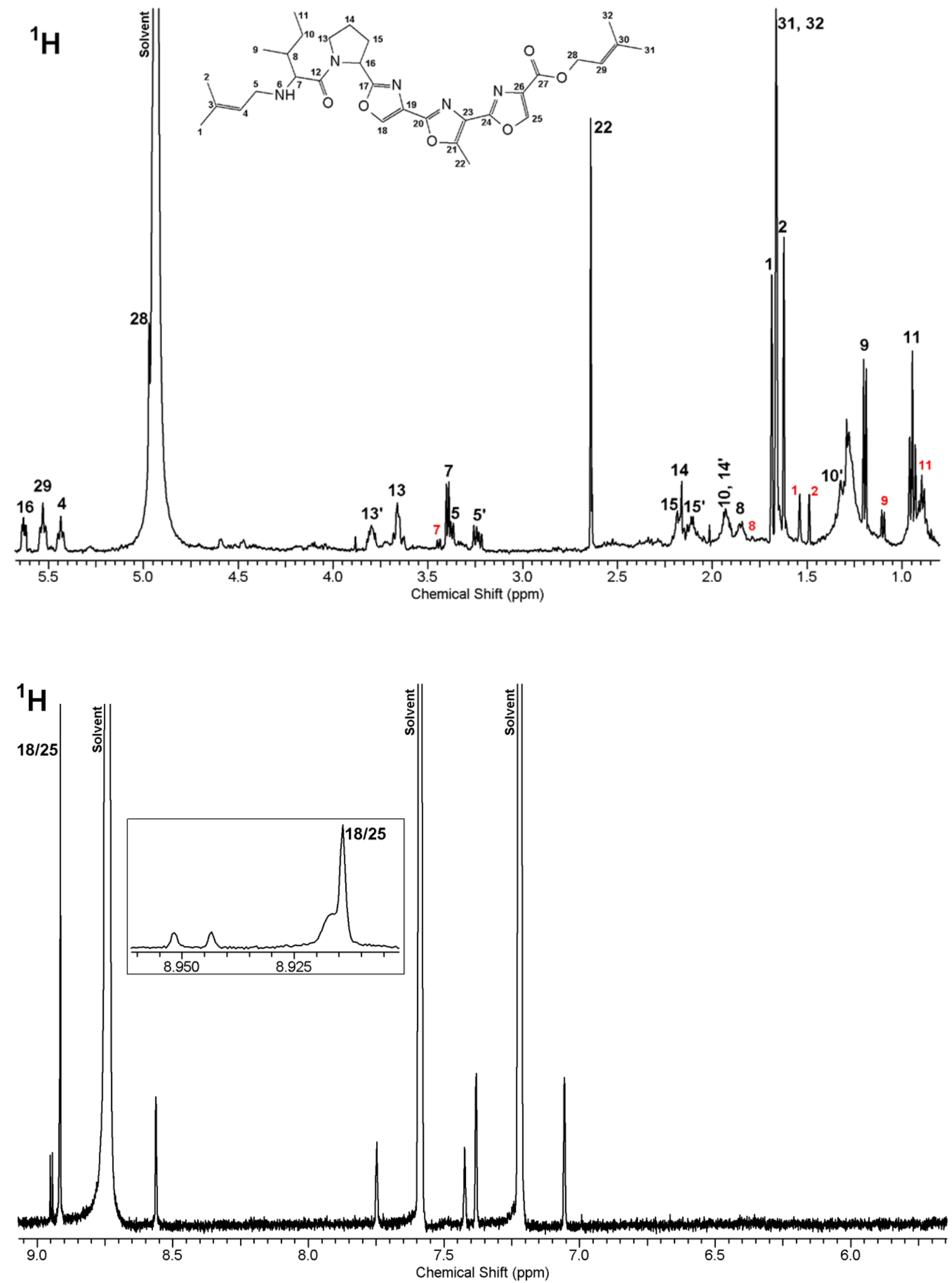

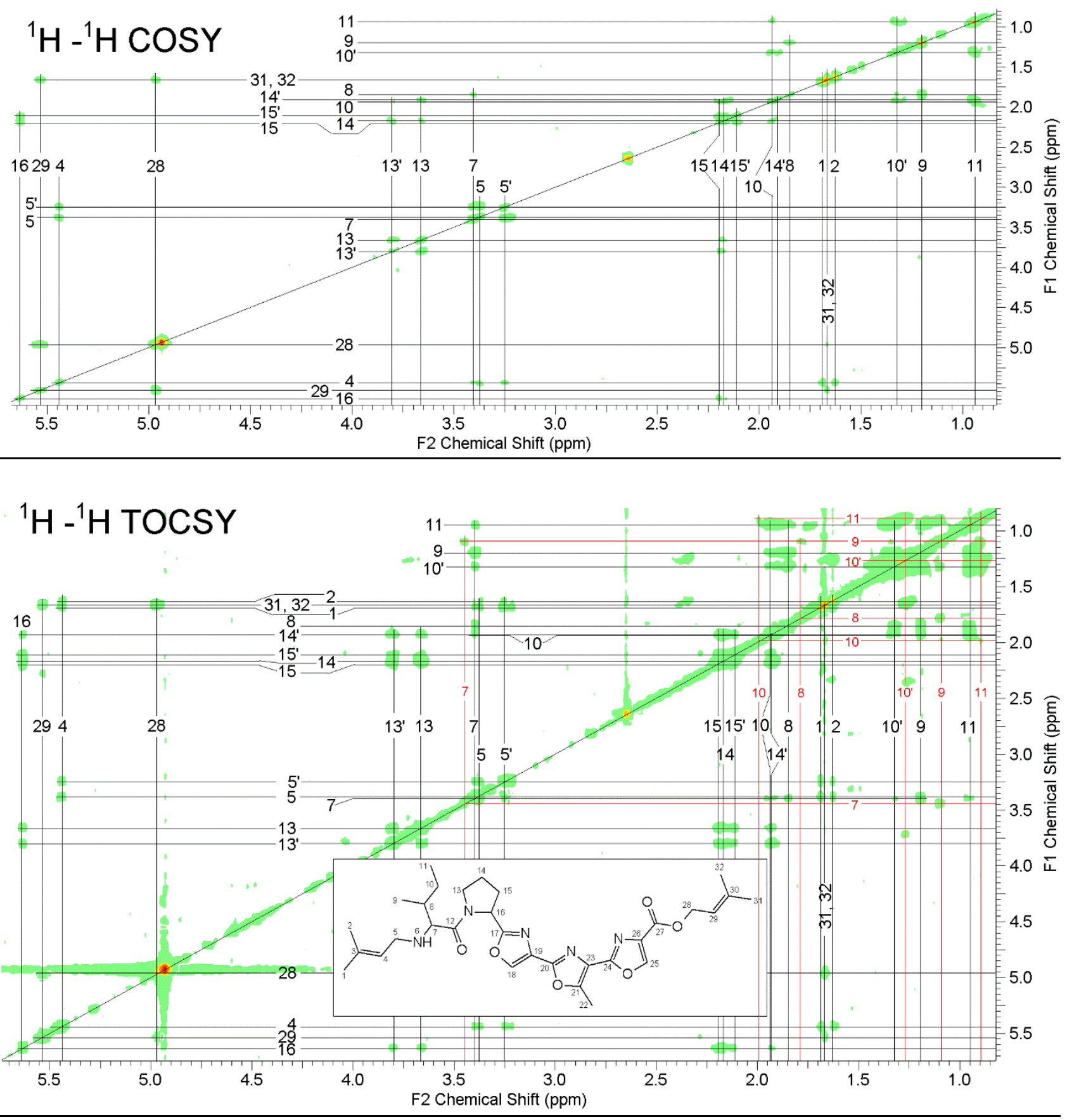

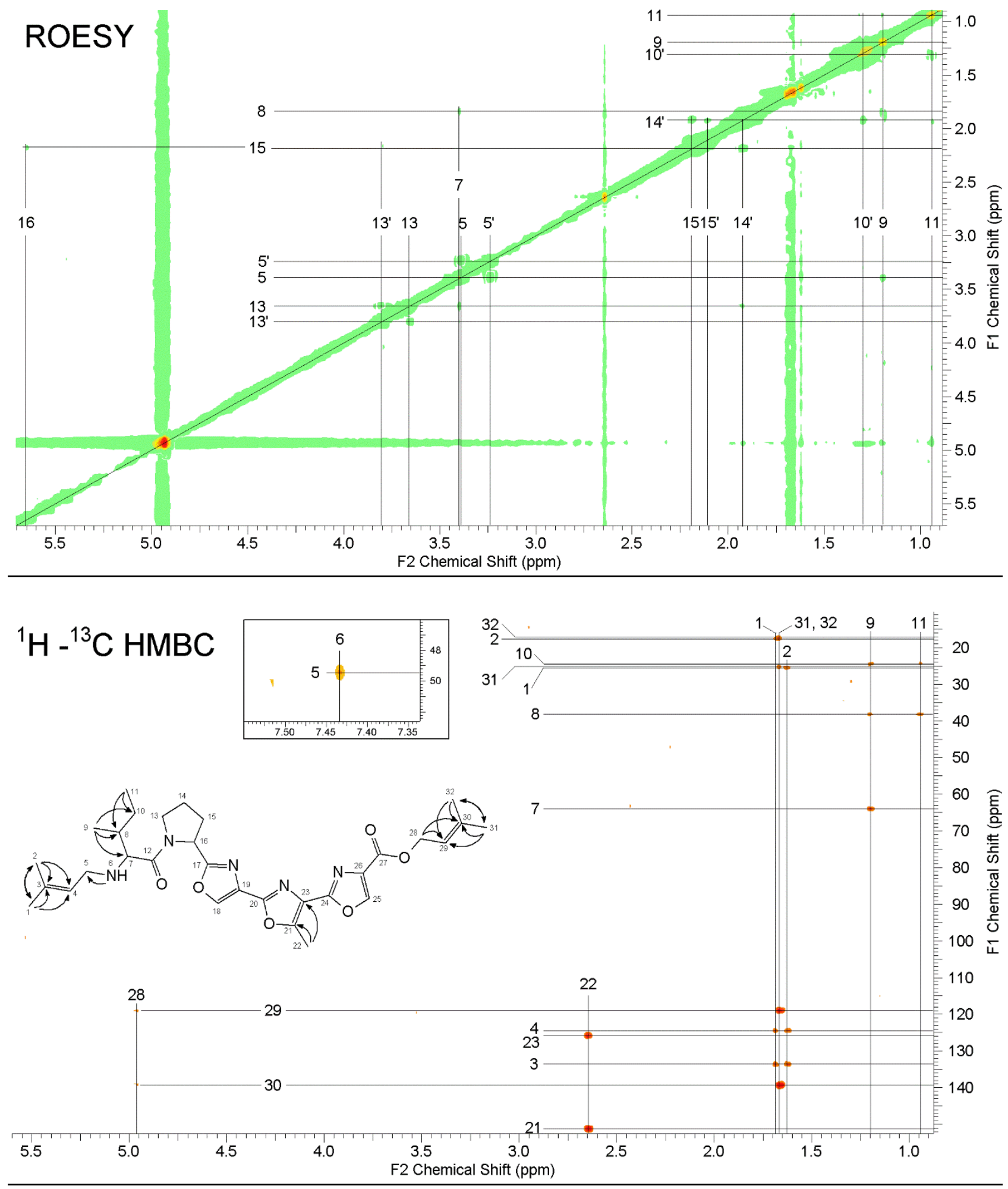

Figure S5. ${ }^{1} \mathrm{H}$ Proton (0.8-5.6 ppm), ${ }^{1} \mathrm{H}$ Proton (6.0-9.0 ppm), ${ }^{1} \mathrm{H}-{ }^{1} \mathrm{H}$ COSY,${ }^{1} \mathrm{H}-{ }^{1} \mathrm{H}$ TOCSY, ROESY and ${ }^{1} \mathrm{H}-{ }^{13} \mathrm{C}$ HMBC spectra of muscoride B. 
Table S2. ${ }^{1} \mathrm{H}$ and ${ }^{13} \mathrm{C}$ NMR spectral data for muscoride B major rotamer (80:20) in pyridine-d 5 . Proton shifts for minor rotamer are in parenthesis.

\begin{tabular}{|c|c|c|c|c|c|c|}
\hline No & $\boldsymbol{\delta}_{\mathbf{C}}(\mathbf{p p m})$ & $\delta_{\mathbf{H}}(\mathbf{p p m})$ & $\operatorname{COSY}^{\mathbf{a}}$ & TOCSY & ROESY & HMBC \\
\hline $\mathbf{1}$ & 25.6 & $1.68(1.54)$ & - & $4,5,5$ & & $2,3,4$ \\
\hline 2 & 17.9 & $1.62(1.49)$ & - & $4,5,5$ & & $1,3,4$ \\
\hline$\overline{3}$ & 133.6 & - & - & - & - & - \\
\hline 4 & 124.6 & 5.43 & 5,5 & $1,2,5,5$ & & \\
\hline 5 & 49.4 & 3.38 & 4,5 & $1,2,4,5,7$ & 5, & \\
\hline 5, & & 3.24 & 4,5 & $1,2,4,5$ & 5 & \\
\hline 6 & - & 7.42 & - & - & & 5 \\
\hline 7 & 64.1 & $3.40(3.44)$ & 8 & $1,4,5^{\prime}, 8,9,10,10^{\prime}, 11$ & 8,13 & \\
\hline 8 & 38.3 & $1.85(1.79)$ & 9 & $7,9,10,11$ & & \\
\hline 9 & nd & $1.20(1.10)$ & 8 & $7,8,10,10^{\prime}, 11$ & $5,8,11$ & $7,8,10$ \\
\hline 10 & 24.7 & $1.93(1.98)$ & $10^{\prime}, 11$ & $7,9,10,11$ & & \\
\hline 10' & & $1.32(1.26)$ & $8,10,11$ & $7,8,9,10,11$ & 11,14 & \\
\hline 11 & nd & $0.94(0.90)$ & 10,10 & $7,8,9,10,10^{\prime}$ & $10^{\prime}, 14^{\prime}$ & 8,10 \\
\hline 12 & nd & - & - & - & - & - \\
\hline 13 & nd & 3.66 & $13^{\prime}, 14,14^{\prime}$ & $13,14,14^{\prime}, 15,15^{\prime}, 16$ & $13^{\prime}$ & \\
\hline 13' & & 3.80 & $13,14,14$ & $13,14,14^{\prime}, 15,15^{\prime}, 16$ & 13,15 & \\
\hline 14 & nd & 2.17 & $13,13^{\prime}, 14^{\prime}, 15^{\prime}$ & $13,13^{\prime}, 14^{\prime}, 15,, 16$ & & \\
\hline 14 & & 1.92 & 14 & $13,13^{\prime}, 15,15^{\prime}, 16$ & 13,15 & \\
\hline 15 & nd & 2.20 & $\left(13^{\prime}\right), 14^{\prime}, 15^{\prime}, 16$ & $13,13^{\prime}, 14^{\prime}, 16$ & 14 & \\
\hline 15' & & 2.11 & 14,15 & $13,13^{\prime}, 14^{\prime}, 15,16$ & $14^{\prime}$ & \\
\hline 16 & nd & 5.63 & 15,15 & $13,13,, 14,14,, 15,15$ & 15 & \\
\hline 17 & nd & - & - & - & - & - \\
\hline 18 & nd & $8.91 *$ & - & - & - & - \\
\hline 19 & nd & - & - & - & - & - \\
\hline 20 & nd & - & - & - & - & - \\
\hline 21 & 151.1 & - & - & - & - & - \\
\hline 22 & 11.2 & 2.64 & - & - & & 21,23 \\
\hline 23 & 126.0 & - & - & - & - & - \\
\hline 24 & nd & - & - & - & - & - \\
\hline 25 & nd & $8.91 *$ & - & - & - & - \\
\hline 26 & nd & - & - & - & - & - \\
\hline 27 & nd & - & - & - & - & - \\
\hline 28 & nd & 4.96 & $29,(31,32)$ & $29,31,32$ & & 29,30 \\
\hline 29 & 119.0 & 5.53 & $28,(31,32)$ & $28,31,32$ & & \\
\hline 30 & 139.3 & - & - & 6 & - & - \\
\hline 31 & 25.3 & 1.66 & $(28,29)$ & 28,29 & & $29,30,32$ \\
\hline 32 & 17.7 & 1.67 & $(28,29)$ & 28,29 & & $29,30,31$ \\
\hline
\end{tabular}


Table S3. Comparison of muscoride B prenyl group $\delta \mathrm{H}$ and $\delta \mathrm{C}$ values to muscoride A (Nagatsu et al., 1995), aeruginosamide (Lawton et al., 1999) and virenamide A and B (Carroll et al., 1996) values.

\begin{tabular}{|c|c|c|c|c|c|c|c|c|c|c|c|}
\hline \multirow[b]{2}{*}{ Location } & \multicolumn{2}{|c|}{$\begin{array}{c}\text { Muscoride } \mathrm{A} \\
\text { forward prenyl } \\
\text { in } \mathrm{CDCl}_{3}\end{array}$} & \multicolumn{2}{|c|}{$\begin{array}{l}\text { Aeruginosamide } \\
\text { forward prenyl } \\
\text { in } \mathrm{CDCl}_{3}\end{array}$} & \multicolumn{2}{|c|}{$\begin{array}{l}\text { Virenamide } \mathrm{A} \\
\text { forward prenyl } \\
\text { in } \mathrm{CDCl}_{3}\end{array}$} & \multicolumn{3}{|c|}{$\begin{array}{c}\text { Muscoride B } \\
\text { Major rotamer 80:20 } \\
\text { (minor rotamer) } \\
\text { in pyridine-d5 }\end{array}$} & \multicolumn{2}{|c|}{$\begin{array}{l}\text { Virenamide } \mathrm{B} \\
\text { reverse prenyl } \\
\text { in } \mathrm{CDCl}_{3}\end{array}$} \\
\hline & $\delta_{c}(p p m)$ & $\delta_{H}(p p m)$ & $\delta_{C}(p p m)$ & $\delta_{H}(p p m)$ & $\delta_{\mathrm{C}}(\mathrm{ppm})$ & $\delta_{H}(p p m)$ & No & $\delta_{c}(p p m)$ & $\delta_{H}(p p m)$ & $\delta_{\mathrm{C}}(\mathrm{ppm})$ & $\delta_{\mathrm{H}}(\mathrm{ppm})$ \\
\hline \multirow[t]{6}{*}{$\mathrm{N}$-terminal } & & & 26.1 & 1.66 & 25.7 & 1.69 & 1 & 25.6 & $1.68(1.54)$ & 27.8 & 0.90 \\
\hline & & & 18.2 & 1.55 & 18.0 & 1.54 & 2 & 17.9 & $1.62(1.49)$ & 24.9 & 0.88 \\
\hline & & & 134.6 & - & 135.4 & - & 3 & 133.6 & - & 144.6 & 5.14 \\
\hline & & & 122.5 & 5.12 & 121.9 & 5.13 & 4 & 124.6 & 5.43 & 112.5 & $4.82 / 4.83$ \\
\hline & & & 48.0 & 3.02 & 48.1 & 3.08 & 5 & 49.4 & 3.37 & & - \\
\hline & & & & 3.10 & & & $5^{\prime}$ & & 3.24 & & \\
\hline \multirow[t]{5}{*}{ C-terminal } & 61.8 & 4.82 & & & & & 28 & nd & 4.96 & & \\
\hline & 118.6 & 5.46 & & & & & 29 & 119.0 & 5.53 & & \\
\hline & 139.1 & & & & & & 30 & 139.3 & - & & \\
\hline & 25.8 & 1.77 & & & & & 31 & 25.3 & 1.66 & & \\
\hline & 18.1 & 1.76 & & & & & 32 & 17.7 & 1.67 & & \\
\hline
\end{tabular}




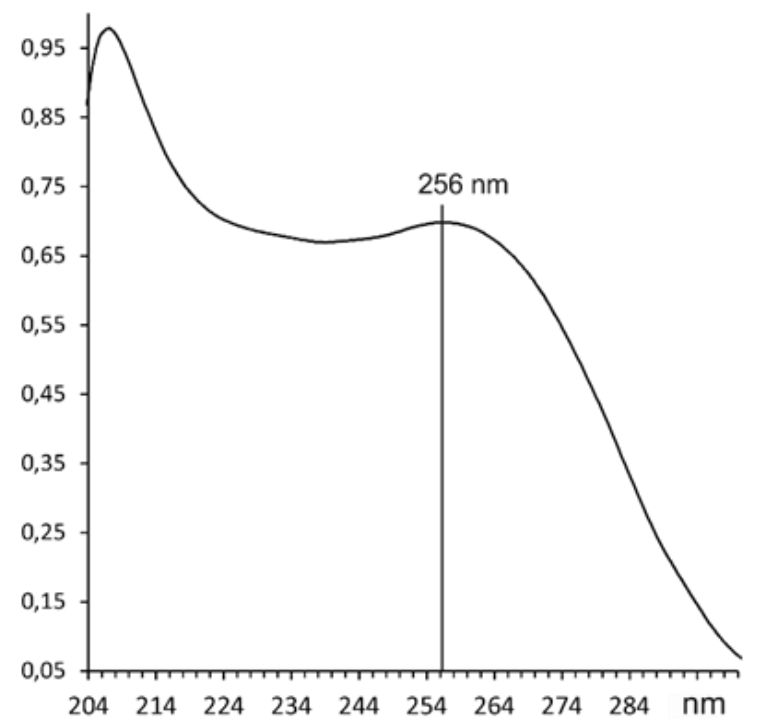

Figure S6. UV spectrum of pure muscoride B shows the maxima at 207 and $256 \mathrm{~nm}$. 

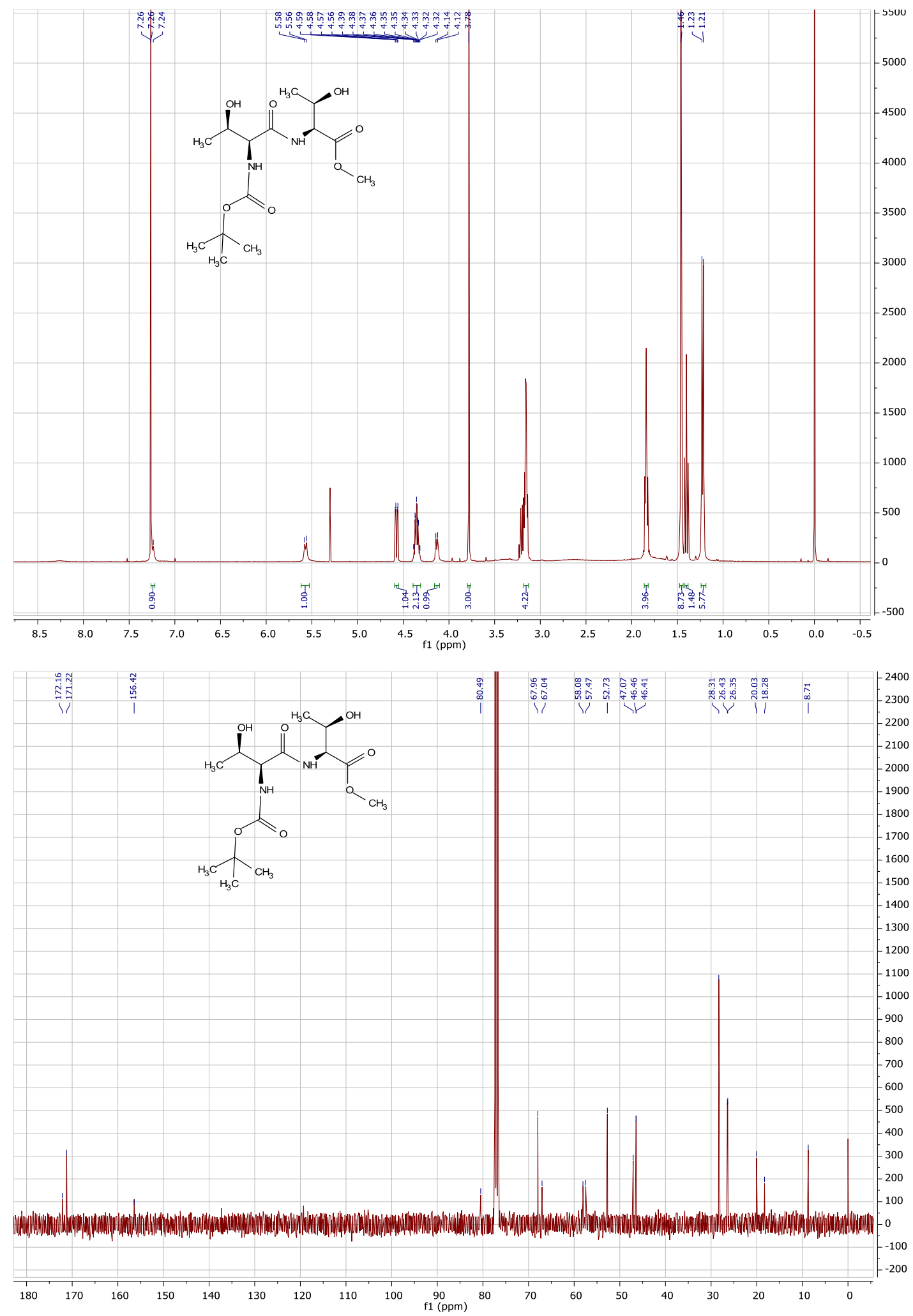

Figure S7. ${ }^{1} \mathrm{H}$ and ${ }^{13} \mathrm{C}$ NMR data of methyl (tert-butoxycarbonyl)-L-threonyl-L-threoninate 4. 

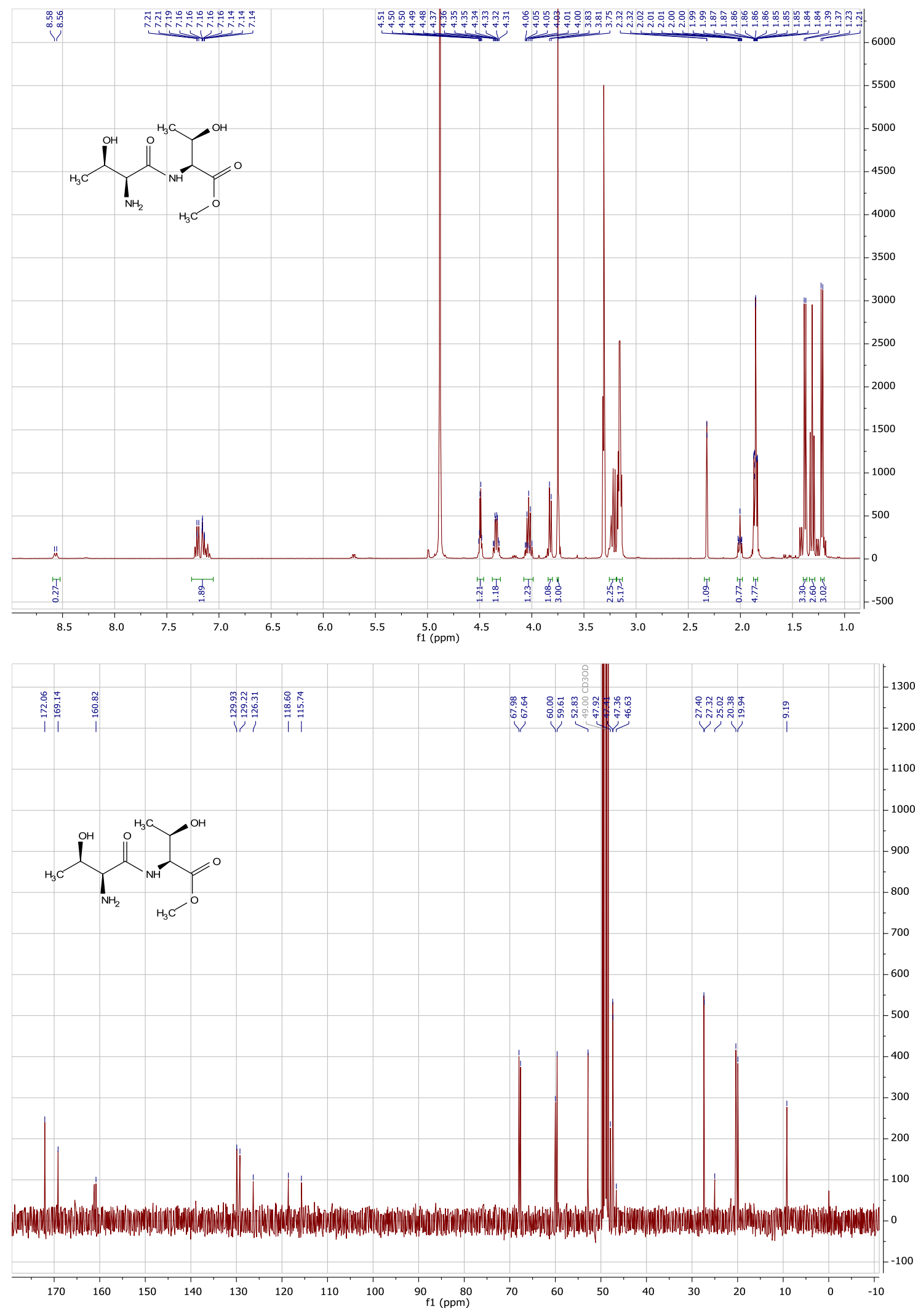

Figure S8. ${ }^{1} \mathrm{H}$ and ${ }^{13} \mathrm{C}$ NMR data of methyl L-threonyl-L-threoninate 5. 

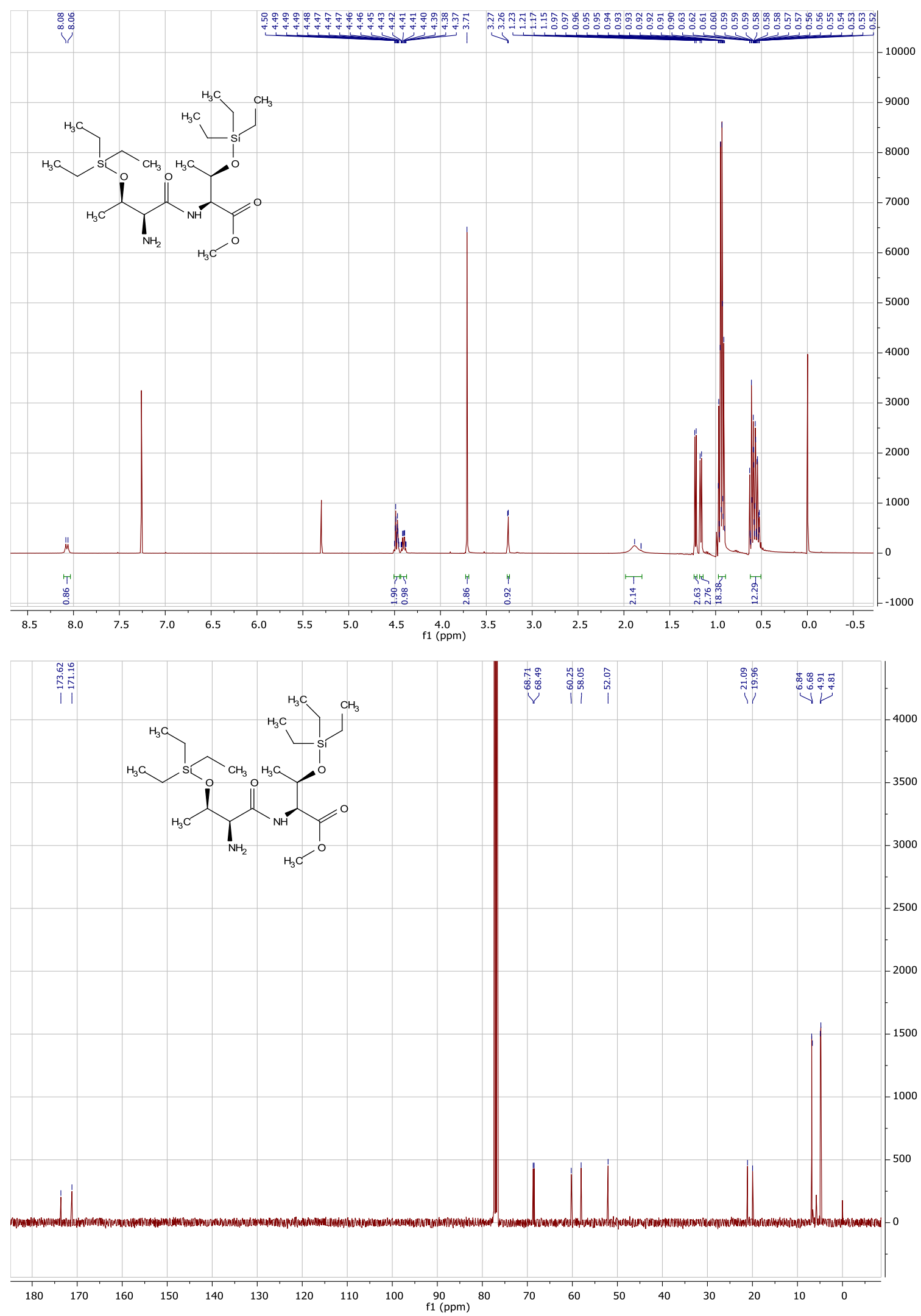

Figure S9. ${ }^{1} \mathrm{H}$ and ${ }^{13} \mathrm{C}$ NMR data of methyl $O$-(triethylsilyl)- $N$-[O-(triethylsilyl)-L-threonyl]-Lthreoninate 6. 

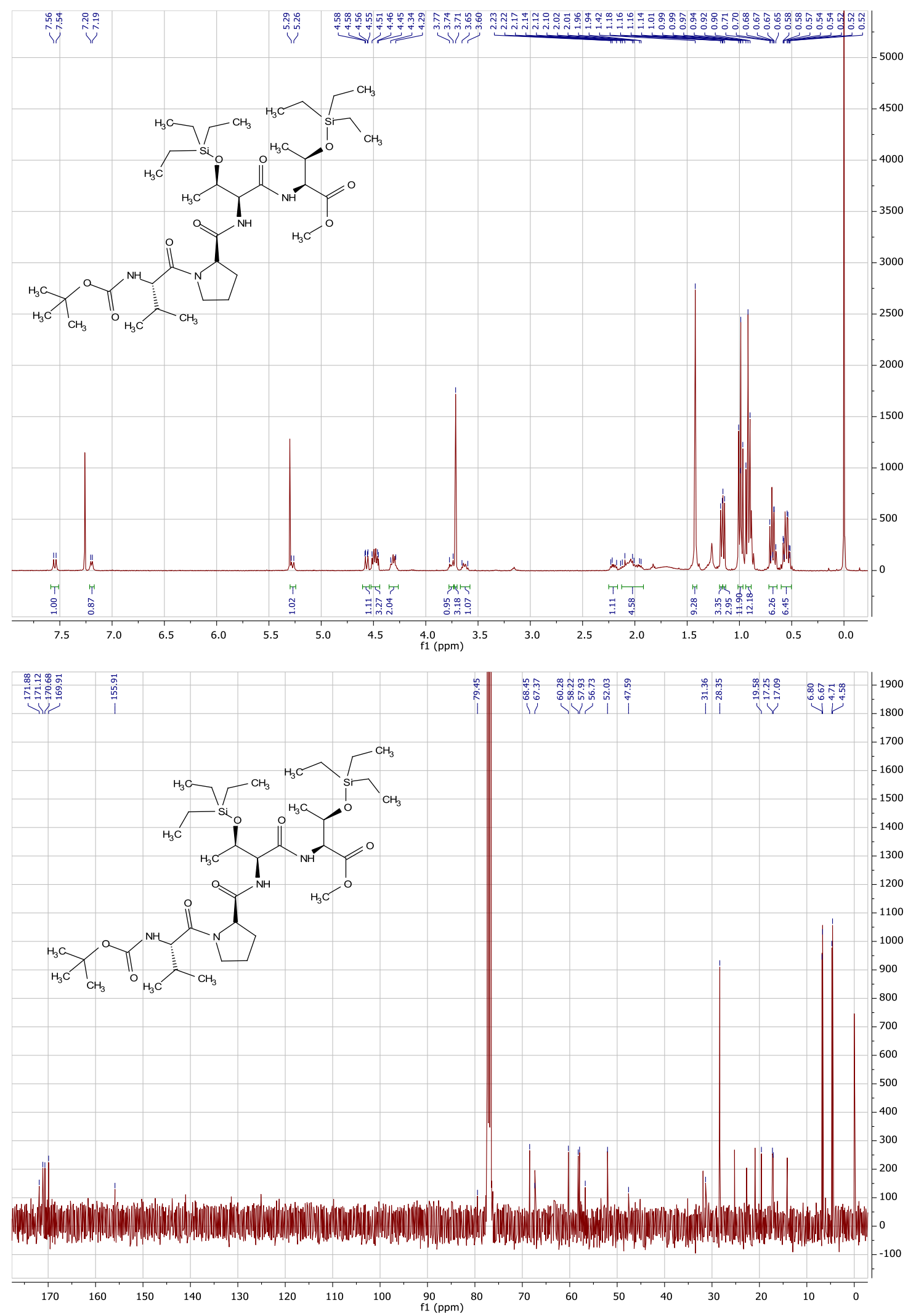

Figure S10. ${ }^{1} \mathrm{H}$ and ${ }^{13} \mathrm{C}$ NMR data of methyl $(3 R)-2-[(3 R)-2-[(\mathrm{S})-1-[(S)-2-[($ tertbutoxycarbonyl)amino]-3-methylbutanoyl]pyrrolidine-2-carboxamido]-3[(triethylsilyl)oxy] butanamido]-3-[(triethylsilyl)oxy] butanoate 8. 


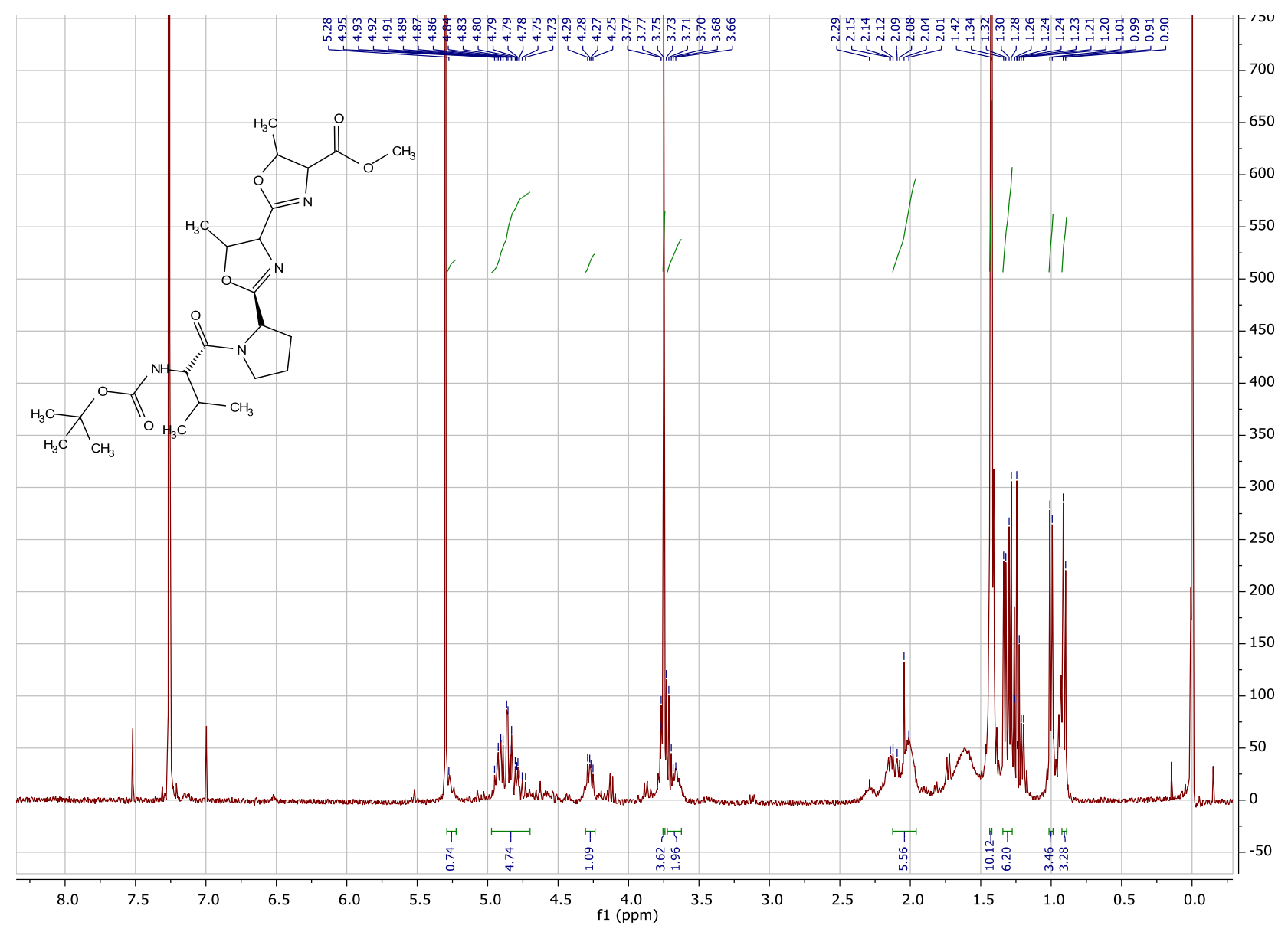

Figure S11. ${ }^{1} \mathrm{H}$ and ${ }^{13} \mathrm{C}$ NMR data of methyl 2'-[(S)-1-[(tert-butoxycarbonyl)-L-valyl]pyrrolidin-2yl]-5,5'-dimethyl-4,4',5,5'-tetrahydro-[2,4'-bioxazole]-4-carboxylate 9. 

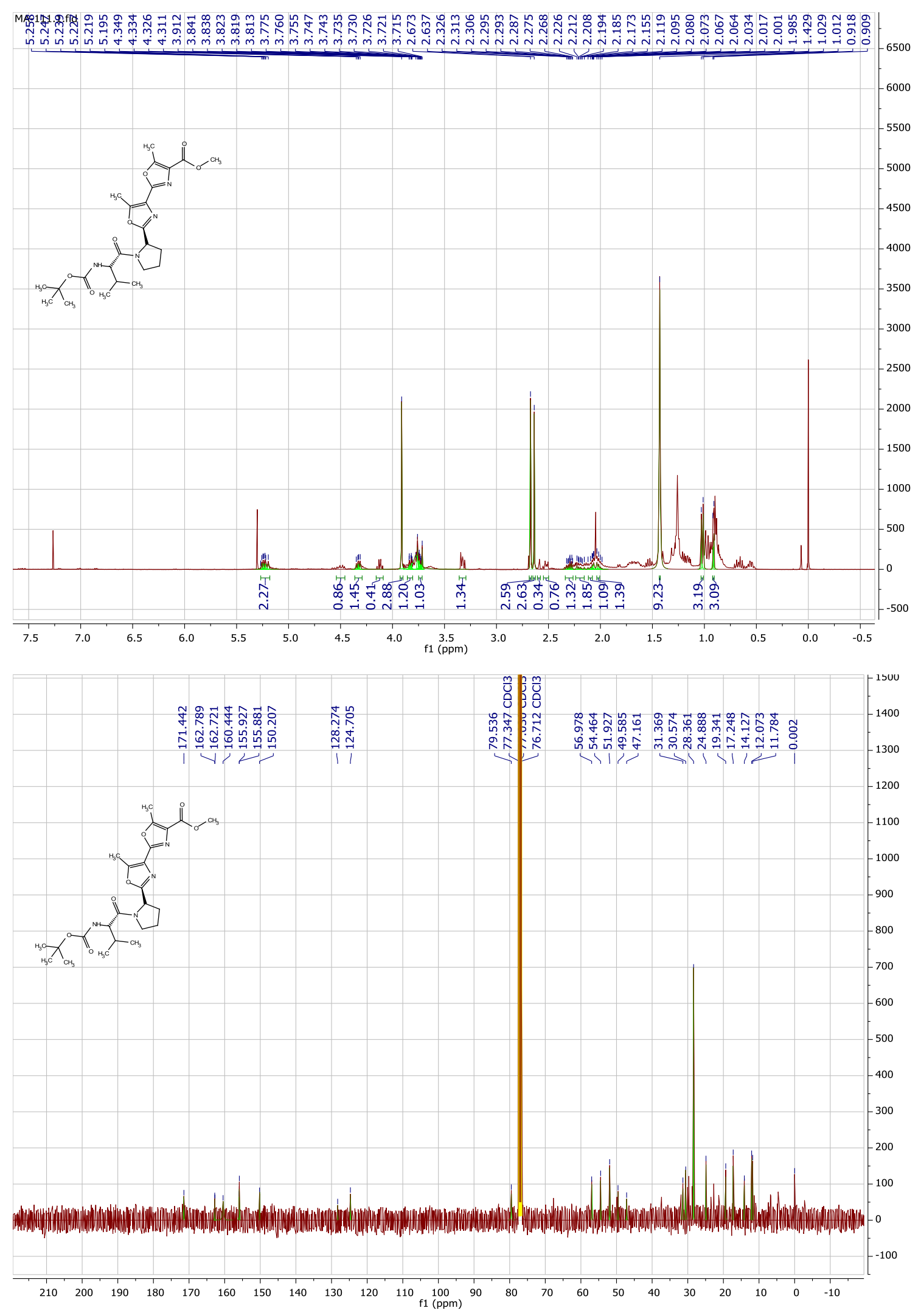

Figure S12. ${ }^{1} \mathrm{H}$ and ${ }^{13} \mathrm{C}$ NMR data of methyl 2'-[(S)-1-[(tert-butoxycarbonyl)-L-valyl]pyrrolidin-2yl]-5,5'-dimethyl-[2,4'-bioxazole]-4-carboxylate $\mathbf{1 0}$. 

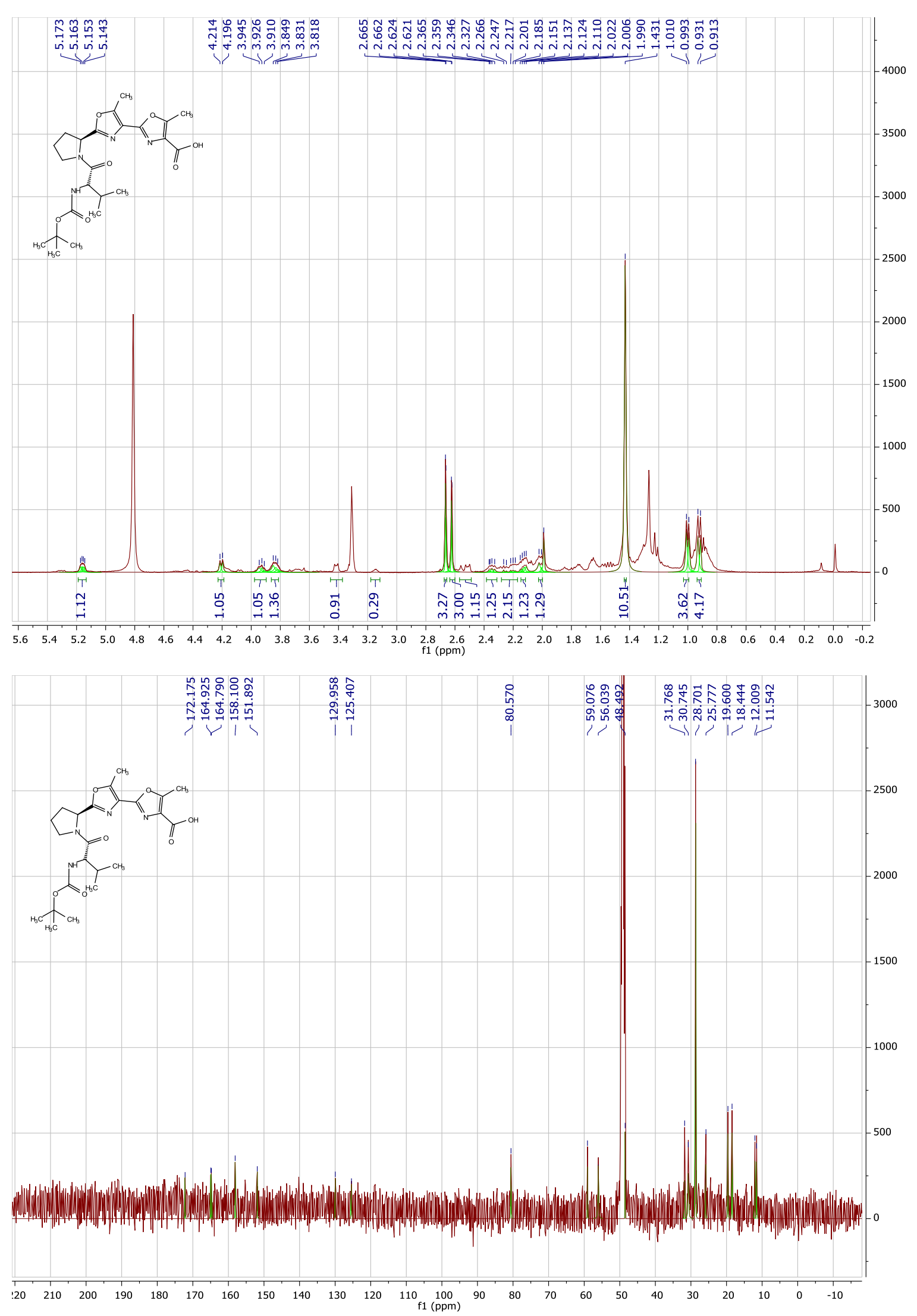

Figure S13. ${ }^{1} \mathrm{H}$ and ${ }^{13} \mathrm{C}$ NMR data of 2'-[(S)-1-[(tert-Butoxycarbonyl)-L-valyl]pyrrolidin-2-yl]-5,5'dimethyl-[2,4'-bioxazole]-4-carboxylic acid 11. 

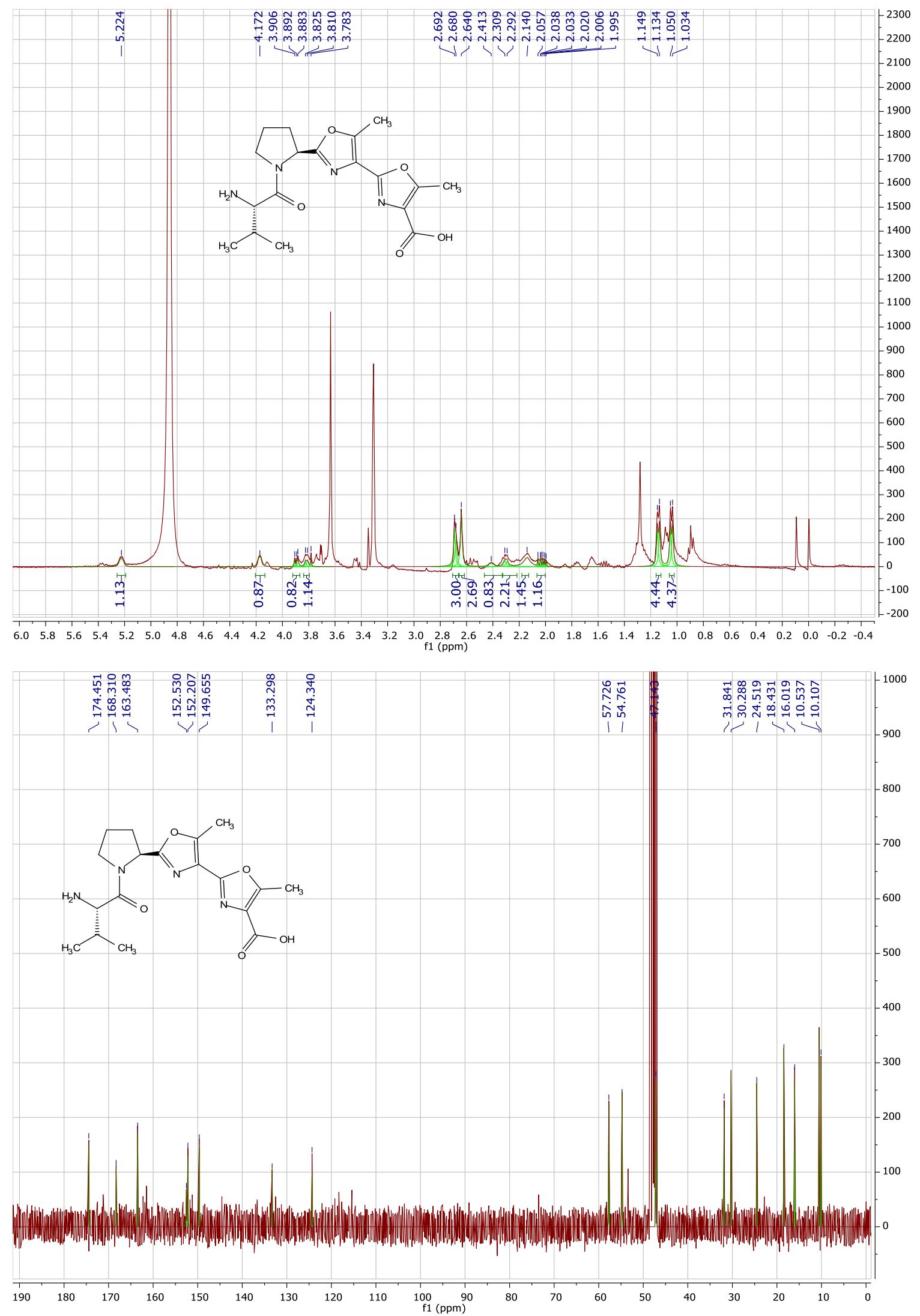

Figure S14. ${ }^{1} \mathrm{H}$ and ${ }^{13} \mathrm{C}$ NMR data of 2'-[(S)-1-(L-Valyl)pyrrolidin-2-yl]-5,5'-dimethyl-[2,4'bioxazole]-4-carboxylic acid $\mathbf{1}$. 

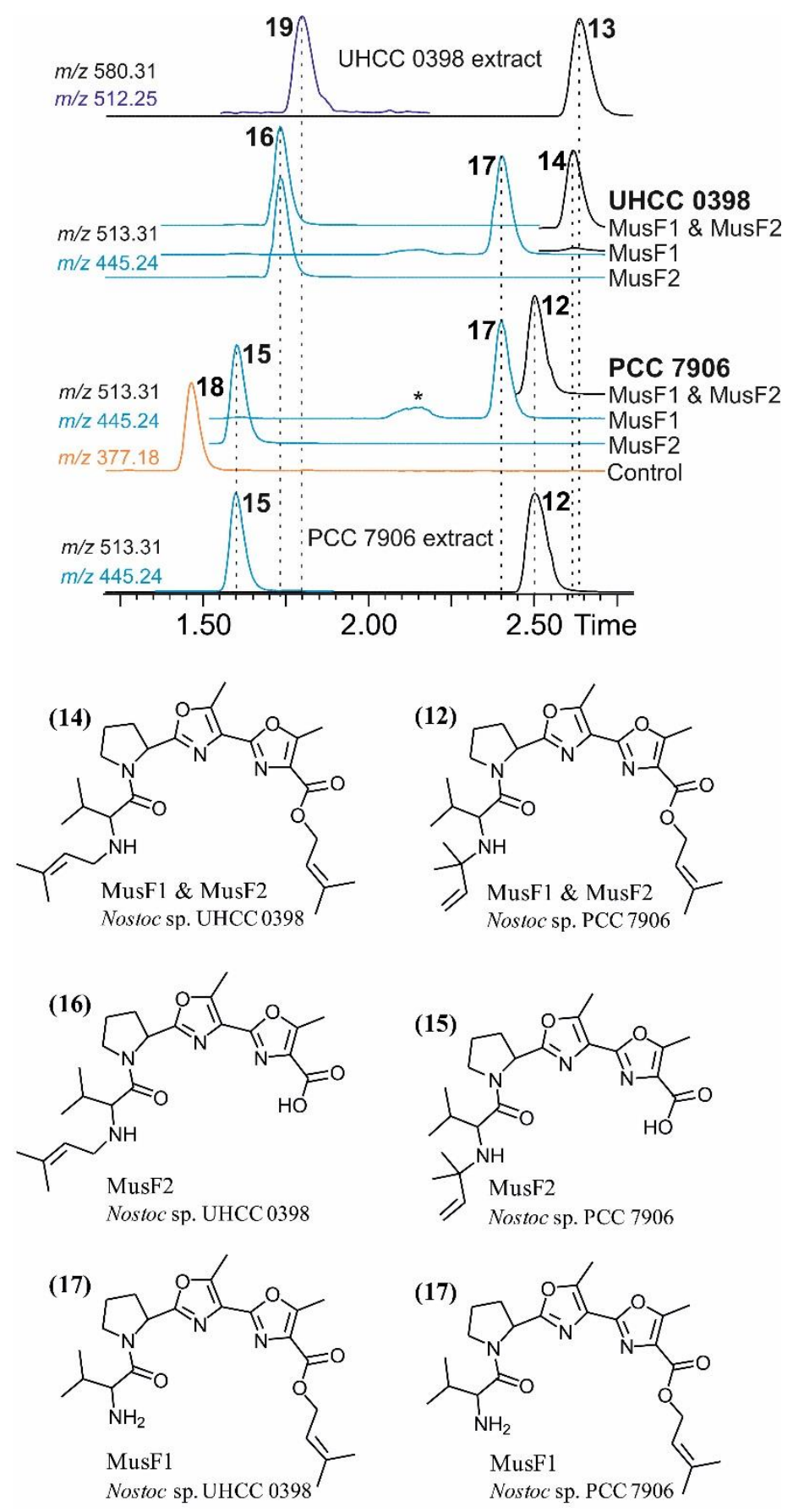

Figure S15 Biochemical assays demonstrating the regiospecific prenylation of the muscoride tetrapeptide precursor with MusF1 and MusF2 prenyltransferases from Nostoc sp. PCC 7906 and Nostoc sp. UHCC 0398. $*=\mathrm{MS}^{\mathrm{E}}$ spectrum different from muscoride spectra. 
Table S4. Peak areas from in vitro prenyltransferase assays and from extracts of Nostoc sp. PCC 7906 and Nostoc sp. UHCC 0398 analyzed with UPLC-QTOF. 1 = muscoride A core.

PCC 7906

\begin{tabular}{ccccccccc}
\hline \multicolumn{2}{l}{ Substrates } & \multicolumn{2}{c}{ Prenyltransferase } & & \multicolumn{3}{c}{ Area } \\
\hline \hline 1 & DMAPP & F1 & F2 & & non-Pr & N-Pr & C-Pr & bis-Pr \\
\hline+ & + & + & - & & 1917 & - & 9701 & - \\
+ & + & - & + & - & 17588 & - & 5 \\
+ & + & + & + & - & - & 53 & 52231 \\
\hline & Nostoc sp. PCC 7906 extract & & - & 1132 & 43 & 52231 \\
\hline
\end{tabular}

UHCC 0398

\begin{tabular}{ccccccccc}
\hline \multicolumn{2}{l}{ Substrates } & \multicolumn{3}{c}{ Prenyltransferase } & \multicolumn{5}{c}{ Area } \\
\hline \hline 1 & DMAPP & F1 & F2 & & non-Pr & N-Pr & C-Pr & bis-Pr \\
\hline+ & + & + & - & & 580 & - & 17227 & 498 \\
+ & + & - & + & 17 & 24344 & - & 118 \\
+ & + & + & + & 15 & 19446 & 2 & 16972 \\
+ & - & - & - & 3282 & - & - & - \\
+ & + & - & - & 2898 & - & - & - \\
\hline
\end{tabular}


Table S5. Synthetic substrates used for the in vitro reactions with MusF1 and MusF2 from Nostoc sp. UHCC 0398.

\begin{tabular}{|c|c|c|c|c|}
\hline Terminus & Name & Formula & MusF1 & MusF2 \\
\hline \multirow[t]{6}{*}{ Carboxy } & 5-Methyl-2-phenyl-1,3-oxazole-4-carboxylic acid & $\mathrm{C}_{11} \mathrm{H}_{9} \mathrm{NO}_{3}$ & + & - \\
\hline & 5-(Oxolan-2-yl)-1,3-oxazole-4-carboxylic acid & $\mathrm{C}_{8} \mathrm{H}_{9} \mathrm{NO}_{4}$ & - & - \\
\hline & 2-Thiophen-2-yl-1,3-thiazole-4-carboxylic acid & $\mathrm{C}_{8} \mathrm{H}_{5} \mathrm{NO}_{2} \mathrm{~S}_{2}$ & + & - \\
\hline & 2-(Acetylamino)-1,3-thiazole-4-carboxylic acid & $\mathrm{C}_{6} \mathrm{H}_{6} \mathrm{~N}_{2} \mathrm{O}_{3} \mathrm{~S}$ & - & - \\
\hline & $\begin{array}{l}\text { 2-(Aminomethyl)-4-methyl-1,3-thiazole-5- } \\
\text { carboxylic acid hydrochloride }\end{array}$ & $\mathrm{C}_{6} \mathrm{H}_{9} \mathrm{ClN}_{2} \mathrm{O}_{2} \mathrm{~S}$ & - & - \\
\hline & 4-Thiazolecarboxylic acid & $\mathrm{C}_{4} \mathrm{H}_{3} \mathrm{NO}_{2} \mathrm{~S}$ & - & - \\
\hline \multirow[t]{3}{*}{ Amino } & VPPP & $\mathrm{C}_{20} \mathrm{H}_{33} \mathrm{~N}_{4} \mathrm{O}_{5}$ & - & + \\
\hline & VPTT & $\mathrm{C}_{18} \mathrm{H}_{33} \mathrm{~N}_{4} \mathrm{O}_{7}$ & - & + \\
\hline & VPTT-Me & $\mathrm{C}_{19} \mathrm{H}_{35} \mathrm{~N}_{4} \mathrm{O}_{7}$ & - & + \\
\hline
\end{tabular}


Table S6. Oligonucleotide primers used to generate mus operon (from Nostoc sp. PCC 7906) expression plasmid.

\begin{tabular}{ll}
\hline Primer Name & Sequence (5'-3') \\
\hline Mus_PCC7906_1st1_5' & cgagctcggtacccggggaaggagatatacATGTCTAAAGTCAAGATCGTCCCTG \\
Mus_PCC7906_1st1_3' & GTTTCTGTTGCTAACGTCTCTAAAGC \\
Mus_PCC7906_1st2_5' & GTTAGCCGGACAAATAGAACCACAAG \\
Mus_PCC7906_1st2_3' & gttttatcagaccgcttctgcgttctgatttaTCAATTCATCCTATAATACAGCTTCGC \\
Mus_PCC7906_2nd1_5' & aattggatcctctagattctccatacAGGAGGAATAATATGAAACCAGAAAATCAAAAGC \\
Mus_PCC7906_2nd1_3' & CCACAAGTCACGATTGTTACTTC \\
Mus_PCC7906_2nd2_5' & GTGCCAATTCTAATGGTGATG \\
Mus_PCC7906_2nd2_3' & ctttagacatgtatatctccttccccgggtaTCACGAAGATTTTTTTGTACCTAG \\
\hline
\end{tabular}


Table S7. Oligonucleotide primers used to generate mus operon (from Nostoc sp. UHCC 0398) expression plasmid.

\begin{tabular}{ll}
\hline Primer Name & Sequence (5'-3') \\
\hline Mus_UHCC0398_1st1_5' & cgagctcggtacccggggaaggagatatacATGTCTAAAGTCAAGATAATCCCTGGAC \\
Mus_UHCC0398_1st1_3' & GTGTTTCACCTTCTGTTGCTAACGTC \\
Mus_UHCC0398_1st2_5' & CATTGAAGCTTTTGCTGATGATG \\
Mus_UHCC0398_1st2_3' & ttatcagaccgcttctgcgttctgatttaTTAATTCATATCATAATATAGTTTCACATGC \\
Mus_UHCC0398_2nd1_5' & aattggatcctctagattctccatacAGGAGGAATAATATGAAACCAGAAAATCAAAAGC \\
Mus_UHCC0398_2nd1_3' & CAGAAGAATTGTTTGCTGTGC \\
Mus_UHCC0398_2nd2_5' & AGCAATTCTGCAAGGATTCTTTG \\
Mus_UHCC0398_2nd2_3' & ctttagacatgtatatctccttccccgggtaTTATTTCGTGCCTAGTATAAACTCTCC \\
\hline
\end{tabular}

